\title{
Effects of cryopreservation and long-term culture on biological characteristics and proteomic profiles of human umbilical cord-derived mesenchymal stem cells
}

Xufeng $\mathrm{Fu}^{1,2^{*+}} \oplus, \mathrm{Bo} \mathrm{Xu}^{1+}$, Jiang Jiang ${ }^{3 \dagger}$, Xing Du${ }^{1}$, Xiaoli Yu${ }^{1}$, Yaping $\mathrm{Yan}^{2}$, Shanshan $\mathrm{Li}^{2}$, Briauna Marie Inglis ${ }^{2}$, Huiming Ma ${ }^{1}$, Hongyan Wang ${ }^{1}$, Xiuying $\mathrm{Pei}^{i^{* *}}$ and Wei $\mathrm{Si}^{2^{*}}$

\begin{abstract}
Background: Human umbilical cord-derived MSCs (hUC-MSCs) have been identified as promising seeding cells in tissue engineering and clinical applications of regenerative medicine due to their advantages of simple acquisition procedure and the capability to come from a young tissue donor over the other MSCs sources. In clinical applications, large scale production is required and optimal cryopreservation and culture conditions are essential to autologous and allogeneic transplantation in the future. However, the influence of cryopreserved post-thaw and long-term culture on hUC-MSCs remains unknown, especially in terms of specific protein expression. Therefore, biological characteristics and proteomic profiles of hUC-MSCs after cryopreserving and long-term culturing were investigated.

Methods: Firstly, hUC-MSCs were isolated from human umbilical cord tissues and identified through morphology, surface markers and tri-lineage differentiation potential at passage 3 , and then the biological characteristics and proteomic profiles were detected and compared after cryopreserving and long-term culturing at passage 4 and continuously cultured to passage 10 with detection occurring here as well. The proteomic profiles were tested by using the isobaric tags for relative and absolute quantification (iTRAQ) labeling technique and differential protein were confirmed by mass spectrometry.

Results: The results showed no significant differences in phenotypes including morphology, surface marker and tri-lineage differentiation potential but have obvious changes in translation level, which is involved in metabolism, cell cycle and other pathways.

Conclusion: This suggests that protein expression may be used as an indicator of hUC-MSCs security testing before applying in clinical settings, and it is also expected to provide the foundation or standardization guide of hUC-MSCS applications in regenerative medicine.
\end{abstract}

Keywords: Human umbilical cord, Mesenchymal stem cells, Cryopreservation, Long-term culture, Proteomic analysis

\footnotetext{
*Correspondence: fuxufeng100@163.com; peixiuying@163.com; siw@lpbr.cn

${ }^{\dagger}$ Xufeng Fu, Bo Xu and Jiang Jiang contributed equally

${ }^{1}$ Key Laboratory of Fertility Preservation and Maintenance of Ministry

of Education, Ningxia Medical University, Yinchuan 750004, China

${ }^{2}$ Yunnan Key Laboratory of Primate Biomedical Research, Institute

of Primate Translational Medicine, Kunming University of Science and Technology, Kunming 650500, China

Full list of author information is available at the end of the article
}

\section{Background}

Mesenchymal stem cells (MSCs) have been regarded as one of the most promising adult stem cells for clinical applications in cell therapy and regenerative medicine due to the capabilities of self-renewal, immunomodulation, multi-lineage differentiation and paracrine function [1]. Moreover, insignificant ethical issues cause MSCs

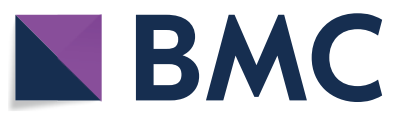

(c) The Author(s) 2020. This article is licensed under a Creative Commons Attribution 4.0 International License, which permits use, sharing, adaptation, distribution and reproduction in any medium or format, as long as you give appropriate credit to the original author(s) and the source, provide a link to the Creative Commons licence, and indicate if changes were made. The images or other third party material in this article are included in the article's Creative Commons licence, unless indicated otherwise in a credit line to the material. If material is not included in the article's Creative Commons licence and your intended use is not permitted by statutory regulation or exceeds the permitted use, you will need to obtain permission directly from the copyright holder. To view a copy of this licence, visit http://creativeco mmons.org/licenses/by/4.0/. The Creative Commons Public Domain Dedication waiver (http://creativecommons.org/publicdomain/ zero/1.0/) applies to the data made available in this article, unless otherwise stated in a credit line to the data. 
to be seen as more advantageous in clinical applications compared to embryonic stem cells [2]. Since the discovery of MSCs in bone marrow in 1966, various tissues have been reported as the sources of MSCs [3]. The isolation of MSCs from human umbilical cord (hUC) has been recognized as a major alternative source. Normally, postnatal tissues after childbirth are discarded as medical waste, and the harvest and utilization of human umbilical cords is noninvasive and causes negligible bioethics concerns [4]. The hUC-MSCs originate from newborns, while the range of bone marrow derived MSC (BM-MSC) donors' ages is wide and the harvest process of bone marrow is invasive [5]. A positive correlation between donor ages and the accumulation of mutations in MSCs has been observed in previous studies [6-8]. Moreover, hUC-MSCs show lower immunogenicity after cell transplantation compared to other sources derived MSCs [9]. Therefore, hUC-MSCs show better superiority than BMMSCs in terms of source and their unique characteristics make hUC-MSCs an extremely valuable candidate for cell therapeutic medicine [5].

Conventionally, the dosages for MSCs transplantations is $10^{6}$ cells $/ \mathrm{kg}$ body weight and the total amount of MSCs for one patient is about $10^{8}$ per cell therapy in clinical trials [10]. Usually, the number of MSCs derived from either autologous or allogeneic tissues is limited, and it is necessary to expand MSCs in vitro before therapy. However, the long-term cultivation of MSCs can result in differentiation-related gene expression and mitochondrial morphology change, reactive oxygen species (ROS) generation and cell senescence, which may deteriorate MSCs features [11]. Therefore, the development of an ideal technique is essential to large-scale MSCs production and storage and it also requires minimal impact on MSCs.

Cell cryopreservation is a widely used technology for long-term storage of cells by cooling the cells to cryogenic temperatures $\left(-196{ }^{\circ} \mathrm{C}\right.$ in liquid nitrogen, for example) [12]. In our previous study, we found that BM-MSCs of a nonhuman primate vitrified with a high level $(5.6 \mathrm{M})$ of the penetrating cryoprotectant either DMSO or ethylene glycol (EG) resulted in changes of a large number of transcripts [13]. Currently, the most widely used method for MSCs cryopreservation is the slow-freezing approach with using a low level of DMSO $(1.5 \mathrm{M})$ as the penetrating cryoprotectant. However, the effects of slow-freezing with a low level of DMSO on the global gene transcripts and proteomics profiles of MSCs have not been studied (Additional file 1: Table S1).

In the present study, we aimed to comprehend the effects of conventional slow-freezing cryopreservation and long-term cultivation on the proteomic profiles of hUC-MSCs. The study will provide a basis for the influence of cryopreservation and cultivation on protein expression, and help facilitate the applications of hUCMSCs in cell therapeutic medicine.

\section{Materials and methods \\ Ethics statement}

The ethical approval was obtained in advance by the Ethics Review Board of Ningxia Medical University and General Hospital of Ningxia Medical University, and informed patient consent for participation was obtained from all subjects.

\section{Isolation and culture of hUCs derived MSCs}

Three hUCs collected from full-term births were used and evaluated separately for this study. The hUC tissues were sanitized with $75 \%$ alcohol for $5 \mathrm{~min}$ and transferred to the lab within $1 \mathrm{~h}$ in Hanks balanced salt solution (HBSS, Sangon biotech, Shanghai, China). The hUCs were cut into $0.5 \times 0.5 \mathrm{~cm}$ pieces with sterile forceps and curved scissors. The pieces were cultured in sterile $10 \mathrm{~mm}$ plastic Petri dishes containing $10 \mathrm{ml}$ of low glucose Dulbecco's modified Eagle's medium (DMEM, Gibco BRL, Grand Island, NY, USA) supplemented with $10 \%$ $(v / v)$ fetal bovine serum (FBS, Gibco) and $1 \%(v / v)$ penicillin/streptomycin (Gibco) at $37{ }^{\circ} \mathrm{C}$ in an incubator with a humidified atmosphere of $5 \% \mathrm{CO}_{2}$ and the medium was refreshed every $48 \mathrm{~h}$. A large amount of fibroblastlike cells around the hUCs tissue pieces appeared 1 week later. The remained hUCs tissues were removed and these primary fibroblast-like cells (passage 0 ) were passaged at $80 \%$ confluency by using $0.25 \%$ trypsin (Gibco). The cells were resuspended in culture medium at a dilution ratio of 1:3 and expanded on a new plastic Petri dish to passage 1 [14]. The morphology, surface markers and differentiation potency of MSCs were identified at passage 3.

\section{Morphological and immunophenotypic characterization of hUC-MSCs}

The morphological characteristics of hUC-MSCs were assessed under a light microscope (Nikon DIAPHOT 300, Japan) at primary culture and upon passaging in all the experimental groups. The morphological images in this present study were taken at $20 \times$ magnification. The expression of cell surface markers were evaluated using a Human MSC Analysis Kit (BD Biosciences, San Jose, CA) with a C6 flow cytometer (BD Biosciences, San Jose, CA) at 3rd, 4th and 10th passages. Briefly, hUC-MSCs were collected and washed with $500 \mu \mathrm{L}$ of PBS (containing 3\% FBS, PBSF) and the concentration was adjusted at $1 \times 10^{6}$ cells $/ \mathrm{mL}$ by using a hemacytometer. Then a total of $100 \mu \mathrm{L}$ of the cell suspension (approximately $5 \times 10^{5}$ cells) was distributed in a $1.5 \mathrm{~mL}$ centrifugal tube and incubated with $5 \mu \mathrm{L}(10 \mu \mathrm{g} / \mu \mathrm{L})$ of human monoclonal 
antibodies against a positive (CD44, CD73, CD90 and CD105) and negative cocktail (including CD34, CD45, CD14, CD19, and HLA-DR) at room temperature for 30 min according to the manufacturer's instructions. Unbound antibodies were washed off with PBS and subsequently the cells were resuspended in $500 \mu \mathrm{L}$ of PBSF mixture before flow cytometric testing [13].

\section{Evaluation of the differentiation potential of hUC-MSCs}

For adipogenic differentiation, hUC-MSCs were seeded into 24-well plates and cultured for $12 \mathrm{~h}$ at a density of $8 \times 10^{4}$ cells per well. Subsequently, the medium was substituted with the adipogenic differentiation medium (Biological Industries, Israel) for 21 days, and the medium was refreshed every 3 days. The induced cells were stained with Oil Red O in a MSCs Adipo-Staining Kit (XP Biomed Ltd., Shanghai, China) according the instructions.

For osteogenic differentiation, hUC-MSCs were seeded into 24-well plates and cultured for $12 \mathrm{~h}$ at a density of $4 \times 10^{4}$ cells per well. Subsequently, the medium was substituted with the osteogenic differentiation medium (Biological Industries, Israel) for 21 days, and the medium was refreshed every 3 days. The induced cells were stained with alizarin red solution in a MSCs Osteo-Staining Kit (XP Biomed Ltd., Shanghai, China) according the instructions.

For chondrogenic differentiation, $2 \times 10^{5}$ hUC-MSCs were pelleted in $15-\mathrm{mL}$ centrifuge tubes and cultured with the chondrogenic differentiation medium (Biological Industries, Israel) for 21 days and the medium was refreshed every 3 days. The chondroid pellets were sectioned by a freezing microtome and the slices were stained with toluidine blue in a MSCs Chondro-Staining Kit (XP Biomed Ltd., Shanghai, China) according the instructions [15].

All differentiation evaluations were repeated 3 times.

\section{Cryopreservation of hUC-MSCs}

The hUC-MSCs from the three donors were harvested at passage 4 and 10 for the cryopreservation assay when the cells reached $80 \%$ confluency. The cell suspension was divided into two equal aliquots at a density of $2 \times 10^{6}$ cells $/ \mathrm{mL}$. One of the aliquots without cryopreservation was sub-cultured in fresh medium for $24 \mathrm{~h}$, and cell viability, immunophenotype surface markers, proliferation and metabolic activity were subsequently examined as a non-frozen control. The other cells were cryopreserved by the conventional cell freezing method with the freezing medium composed of DMEM medium supplemented with $10 \%$ FBS and 10\% DMSO. The mixture of freezing medium and hUC-MSC suspension $(1 \mathrm{~mL})$ in a $1.8 \mathrm{~mL}$ cryovial containing a density of $1 \times 10^{6}$ cells $/ \mathrm{mL}$ was cooled at approximately $1{ }^{\circ} \mathrm{C} / \mathrm{min}$ from 25 to $-80{ }^{\circ} \mathrm{C}$ in a freezing container (Nalgene, Rochester, NY) for $12 \mathrm{~h}$ and then the cryovials were plunged directly into liquid nitrogen for storage. This is the most commonly used method and equipment for MSCs cryopreservation in laboratories all over the world [16, 17]. After being stored in liquid nitrogen for $24 \mathrm{~h}$, the cells were rapidly warmed by immersing the cryovial in a $37{ }^{\circ} \mathrm{C}$ water bath for $5 \mathrm{~min}$. Post-thawed cells were cultured for $24 \mathrm{~h}$ for recovery and subsequently evaluated as described in the following assays. The cryopreserved MSCs (abbreviated as "C" from now on) were subcultured for 24 and $48 \mathrm{~h}$ at $\mathrm{P} 4$ and P10, respectively, and non-cryopreserved MSCs (abbreviated as "N" from now on) cultured for 24 and $48 \mathrm{~h}$ at same passages were used as controls. The schematic illustration of the procedure was shown in Fig. 1. A total of 8 groups of hUC-MSCs were involved in this study as follows: non-cryopreserved and sub-cultured for $24 \mathrm{~h}$ at $\mathrm{P} 4$ (P4N24), cryopreserved and sub-cultured for $24 \mathrm{~h}$ at P4 (P4C24), non-cryopreserved and sub-cultured for $48 \mathrm{~h}$ at P4 (P4N48), cryopreserved and sub-cultured for $48 \mathrm{~h}$ at $\mathrm{P} 4$ (P4C48), non-cryopreserved and sub-cultured for $24 \mathrm{~h}$ at P10 (P10N24), cryopreserved and sub-cultured for $24 \mathrm{~h}$ at P10 (P10C24), non-cryopreserved and subcultured for $48 \mathrm{~h}$ at P10 (P10N48) and cryopreserved and sub-cultured for $48 \mathrm{~h}$ at P10 (P10C48).

\section{Measurement of cell viability}

The viability of cells from P4N24, P4C24, P4N48, P4C48, P10N24, P10C24, P10N48 and P10C48 groups were measured by trypan blue dye (Solarbio, Beijing, China) exclusion assay. Ten $\mu \mathrm{L}$ of cell suspension was mixed 10 $\mu \mathrm{L} 0.4 \% w / \nu$ trypan blue solution for $5 \mathrm{~min}$, and the dead cells were stained and counted with a haemocytometer under a light microscope.

\section{Proteomics analysis and targeted quantitative detection of hUC-MSCs}

The cells from non-cryopreserved groups (P4N24, P4N48, P10N24, P10C24, and P10N48) and cryopreserved groups (P4C24, P4C48, P10C24 and P10C48) groups were collected for proteomic profile detection. The proteomics procedures were performed by PTM Biolabs Lnc. (Hangzhou, Zhejiang, China). Briefly, a cell sample was sonicated by high intensity ultrasonic processor in lysis buffer of urea and protease inhibitor cocktail, and the remaining cell debris was removed by centrifugation. The protein concentration of the supernatant was collected and quantified with BCA kit (Thermo Fisher, USA), and prokaryotic standard protein was added for detecting quality control [18]. Then, the protein solution was reduced with dithiothreitol and alkylated with iodoacetamide, and the urea concentration was diluted 


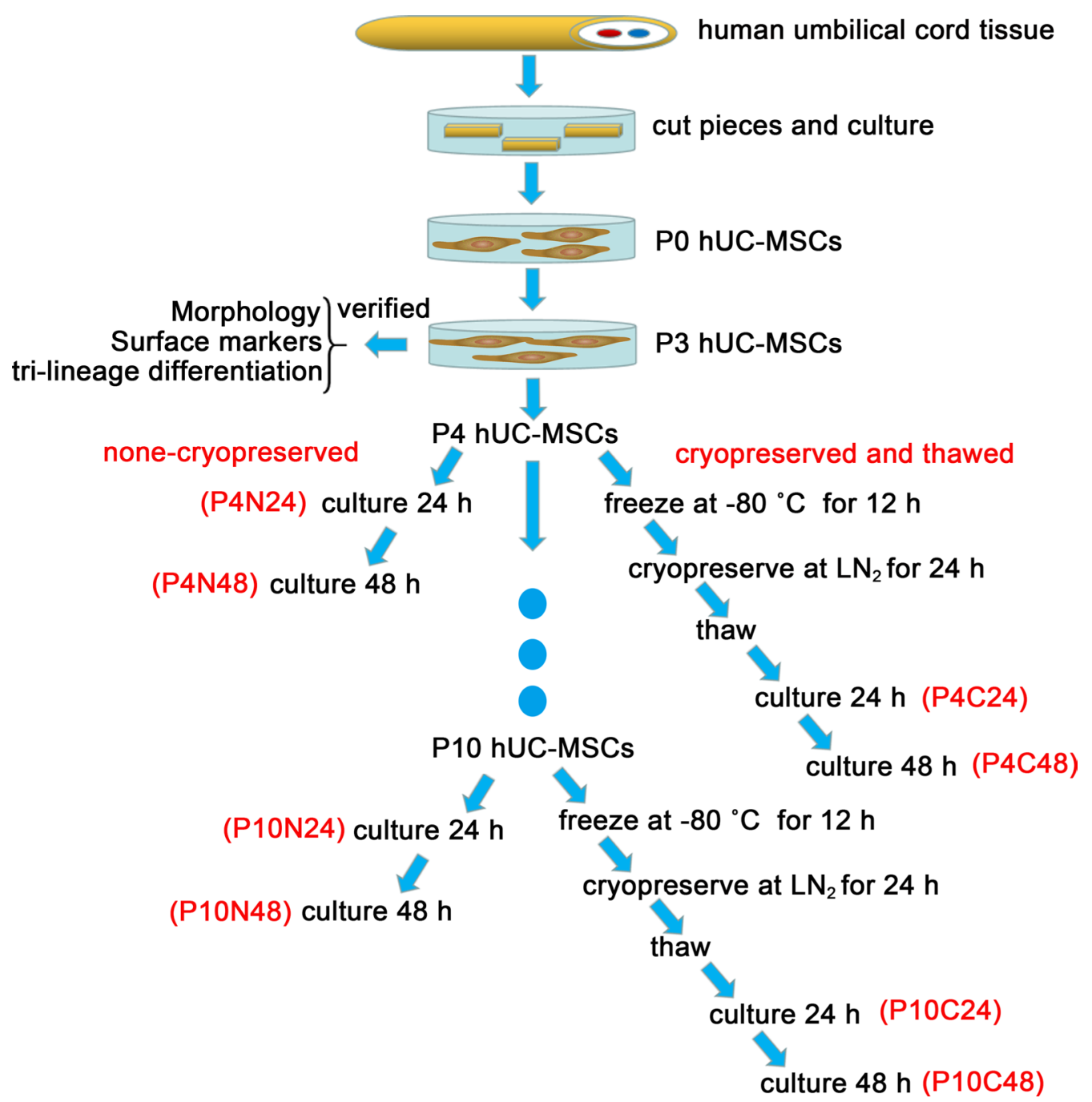

Fig. 1 A schematic illustration of the procedure for hUC-MSCs cryopreservation and long-term culture. LN 2 : liquid nitrogen. P4N24: non-cryopreserved and sub-cultured for $24 \mathrm{~h}$ at P4. P4C24: cryopreserved and sub-cultured for $24 \mathrm{~h}$ at P4, P4N48: non-cryopreserved and sub-cultured for $48 \mathrm{~h}$ at P4, P4C48: cryopreserved and sub-cultured for $48 \mathrm{~h}$ at P4, P10N24: non-cryopreserved and sub-cultured for $24 \mathrm{~h}$ at P10, P10C24: cryopreserved and sub-cultured for $24 \mathrm{~h}$ at P10, P10N48: non-cryopreserved and sub-cultured for $48 \mathrm{~h}$ at P10, P10C48: cryopreserved and sub-cultured for $48 \mathrm{~h}$ at P10

by adding tetraethylammonium bromide, and then the protein samples were digested by trypsin. After trypsin digestion, the peptide was desalted and processed according to the manufacturer's protocol for TMT/iTRAQ kit. The tryptic peptides were fractionated into fractions by high $\mathrm{pH}$ reverse-phase HPLC using Agilent 300 Extend C18 column, and the peptides were dissolved by acetonitrile and analyzed by tandem mass spectrometry in Q ExactiveTM Plus (Thermo) coupled online to the EASYnLC 1000UPLC. The data of tandem mass spectrometry were processed using Maxquant search engine (v.1.5.2.8) and annotation results from database were collected for analysis. Quantitative analysis of differentially expressed proteins was also performed depending on Parallel Reaction Monitoring (PRM) technology by PTM Biolabs Lnc. according to their commercial manufacturer's instructions. The pre-processing of samples as well as proteomics analysis, besides, quantitative analysis was used as a standard to quantify special protein from samples.

\section{Statistical analysis}

The data from viability and markers expression were significantly analyzed statistically using Graphpad software (GraphPad Prism; Graphpad Software, Inc., San Diego, CA) and presented as the mean \pm SD. Comparative assessment of mean value among various 
factors was performed using ANOVA and unpaired $t$ test and a $P$-value $<0.05$ was considered statistically significant.

Differential protein screening was based on a 1.3fold change, and the ratio between the samples at more than 1.3-fold change or less than 1/1.3-fold change were considered up-regulated or down-regulated trend $P$-value $<0.05$. For further study of the hierarchical clustering, all the categories were obtained and enriched in clusters depending on $P$-value $<0.05$, and the cluster membership were visualized by a heat map using the "heatmap.2" function from the "gplots" R-package. Proteins were classified by Gene Ontology (GO) annotation, which was derived from the UniProtGOA database (www. http://www.ebi.ac.uk/GOA/). The pathways of different proteins were classified according to the Kyoto Encyclopedia of Genes and Genomes (KEGG) database website.

Identified proteins domain functional description was annotated by InterProScan based on InterPro (http://www.ebi.ac.uk/interpro/) domain database. These enrichment analyses were tested according to the database of identified proteins and employed two-tailed Fisher's exact test, all terms with corrected $P$-values $<0.05$ were considered significantly enriched differentially expressed proteins.

\section{Results}

\section{Basic characterization of hUC-MSCs}

During primary culture, the spindle-shaped and fibroblast-like cells were dispersed around the shredded umbilical cord tissues. These cells grew adhesively in plastic dishes in a scattered manner, formed colonies and appeared heterogeneously regarded as hUC-MSCs of passage 0 (P0, Fig. 2a). The hUC-MSCs colonies at passage 0 were extended to passage 3 (P3) with subsequent subculture, and the P3 hUC-MSCs also showed a spindle-shaped and fibroblast-like morphology (Fig. 2b). The surface marker profiles of the hUC-MSCs were analyzed at P3 by flow cytometry. The percentage of positively expressed surface markers was $100.0 \pm 0.0 \%$ of $\mathrm{CD} 44,99.3 \pm 0.2 \%$ of $\mathrm{CD} 73$ and $85.0 \pm 1.4 \%$ of $C D 105$, and the percentage of negative expressed cocktail surface markers was $0.2 \pm 0.1 \%$ (Fig. 2c-h). After adipogenic, osteogenic and chondrogenic differentiation, the P3 hUC-MSCs formed numerous neutral lipid droplets in the cytoplasm identified by Oil Red O staining (Fig. 2i), mineral accumulation and bone nodules formation was identified by alizarin red staining (Fig. 2j) and proteoglycan and hyaluronic acid accumulation was identified by alcian blue staining (Fig. 2k).

\section{Effect of long-term culture and cryopreservation} on the biological characteristics of hUC-MSCs

As shown in Fig. 3a, the viability of hUC-MSCs were significantly decreased after instant freezing and thawing (abbreviated as "C" groups from now on) compared to non-cryopreserved control (abbreviated as " $\mathrm{N}$ " groups from now on) either at passage $4(\mathrm{P} 4, \mathrm{~N}$ vs. C, $99.61 \pm 0.22 \%$ vs. $94.42 \pm 1.53 \%$ ) or passage 10 (P10, N vs. C, $99.44 \pm 0.51$ vs. $93.82 \pm 2.13 \%$ ). After a sub-culture for $24 \mathrm{~h}$ or $48 \mathrm{~h}$ post thawing, the hUC-MSCs either at $\mathrm{P} 4$ or $\mathrm{P} 10$ remained to possess a high level expression of positive surface markers (CD44, CD73, CD90 and CD105) and barely expressed negative markers of MSCs, and no significant differences were observed compared to non-cryopreserved controls. The results suggested that the expression of surface markers was not affected by cryopreservation and long-term culture (Fig. 3b). The morphology of cells from non-frozen control and cryopreserved groups following a $24 \mathrm{~h}$ and $48 \mathrm{~h}$ sub-culture post thawing are shown in Fig. 3c. No obvious morphological changes were observed among the eight groups. Similar to the cells from control groups, the differentiation potency of hUCs from N24, N48, C24 and C48 groups at P4 and P10 showed no obvious difference evaluated by adipogenic (Fig. 4a), osteogenic (Fig. 4b) and chondrogenic differentiation (Fig. 4c).

\section{Effect of cryopreservation and long-term culture on proteome profiles of hUC-MSCs}

The number of significantly modulated proteins of hUCMSCs among the 8 groups are summarized in Fig. 5a. These results indicated that the proteome profiles of hUC-MSCs were affected by either long-term culture or cryopreservation. The functional enrichment analysis according to Gene Ontology (GO) of differentially expressed proteins among hUC-MSCs from the 8 groups was summarized in Fig. 5b-d. The heatmap graphs of the GO display the distribution of the biological terms presented in molecular function (Fig. 5b), biological process (Fig. 5c) and cellular component (Fig. 5d). In molecular function, protein kinase activity and microtubule motor activity were affected by continuous culture from $24 \mathrm{~h}$ to $48 \mathrm{~h}$ at P4 without cryopreservation (P4N24 vs. P4N48). Retinoid, isoprenoid binding and cytokine activity were affected by long-term culture from P4 to P10 without cryopreservation (P4N48 vs. P10N48). Oxidoreductase, hydrolase and peptidyl-proline dioxygenase were affected by cryopreservation and sub-culture for $48 \mathrm{~h}$ at P10 compared to P4 (P4C48 vs. P10C48), which were shown in Fig. 5b. In biological process as shown in Fig. 5c, regulation of nuclear division was affected by continuous culturing from $24 \mathrm{~h}$ to $48 \mathrm{~h}$ at $\mathrm{P} 4$ without 
a

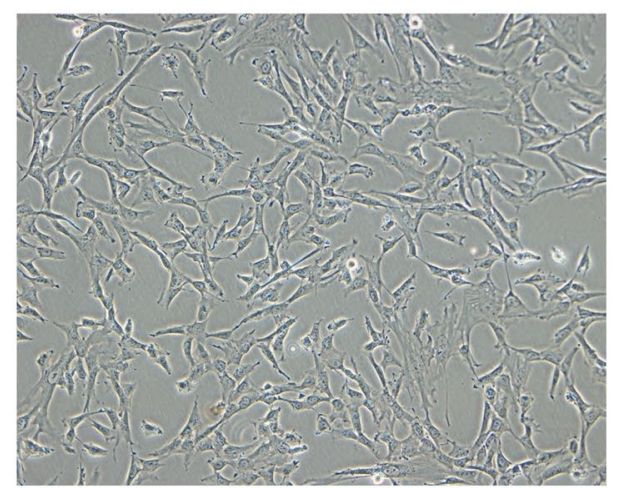

b
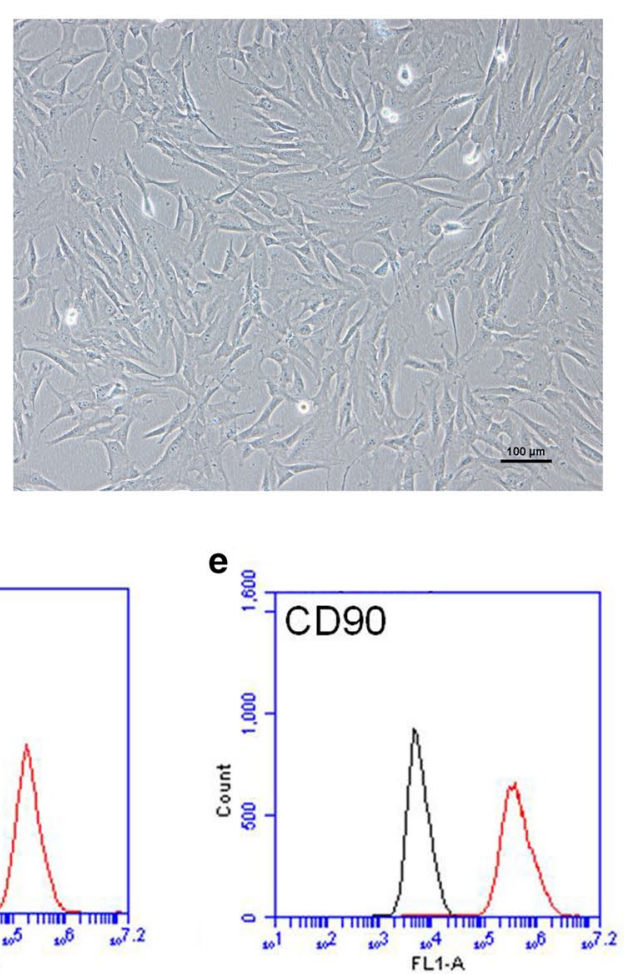

h

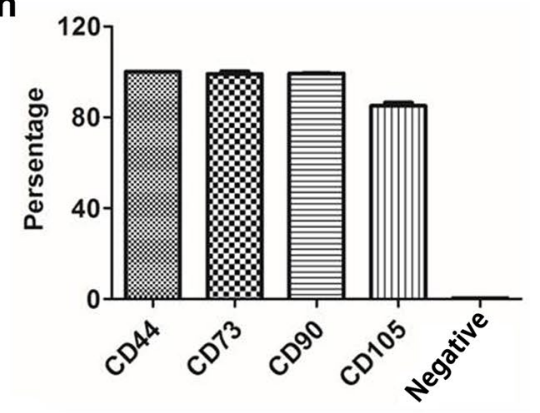

$\mathbf{k}$

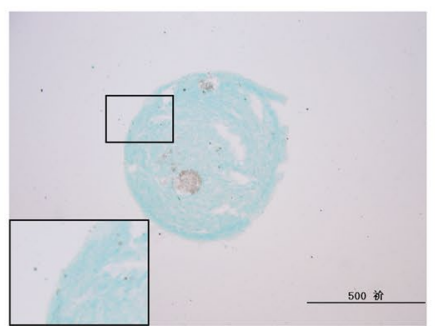

Fig. 2 Fibroblast-like morphology of MSCs at passage 0 (a) and passage 3 (b). Scale bars: $100 \mu$ m. c-g Surface markers expression on human umbilical cord-derived MSCs at passage 3 analyzed using flow cytometry. Black lines represent isotype control. h Quantitative profile of surface markers expression $(n=3)$. i-k Differentiation potency of MSCs at passage 3. i Adipogenic differentiation (oil red staining, $\times 200$ ); $\mathbf{j}$ Osteogenic differentiation (alizarin red staining, $\times 100$ ); $\mathbf{k}$ Chondrogenic differentiation (alcian blue staining, $\times 50$ ). Scale bars: i was $50 \mu \mathrm{m}, \mathbf{j}$ was $100 \mu \mathrm{m}$ and $\mathbf{k}$ was $500 \mu \mathrm{m}$ 


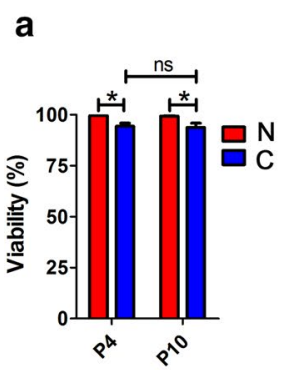

\section{b}

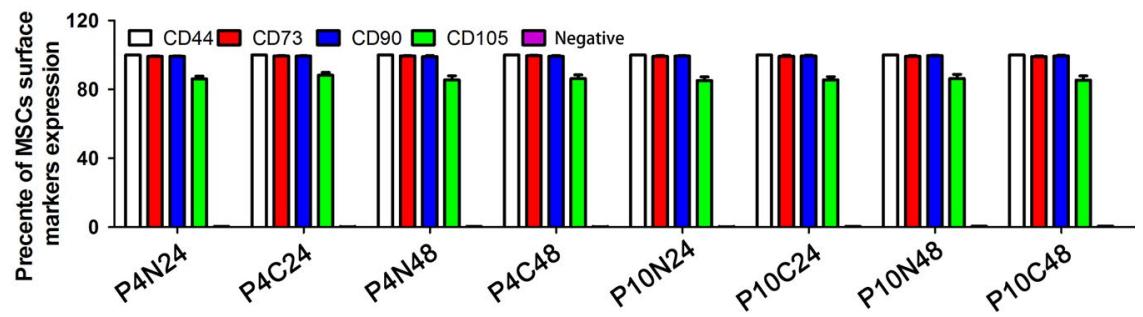

c

$24 \mathrm{~h}$

C

$\mathrm{N}$
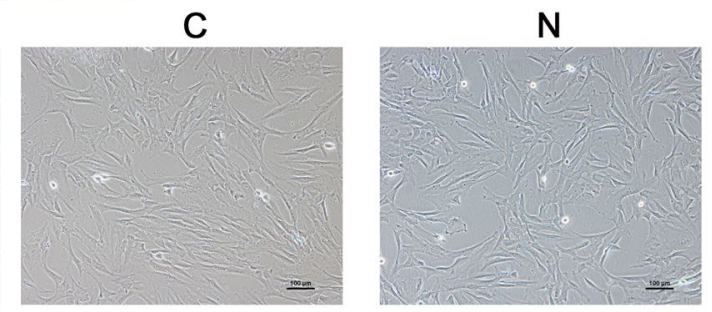

$48 \mathrm{~h}$
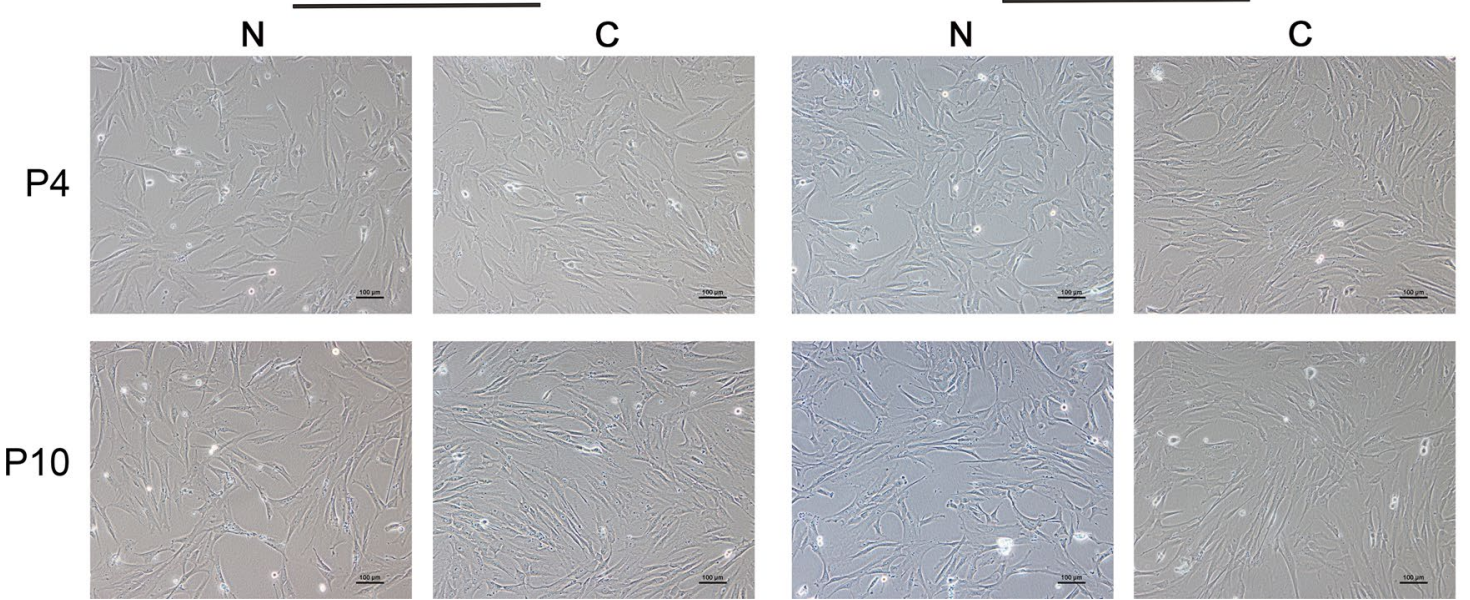

Fig. 3 Comparison of the cell viability $(n=3)(\mathbf{a})$, surface markers expression $(n=3)(\mathbf{b})$ and morphology $(\mathbf{c})$ between non-cryopreserved $(N)$ and cryopreserved (C) groups after being sub-cultured for $24 \mathrm{~h}$ or $48 \mathrm{~h}$ at $\mathrm{P} 4$ and P10, respectively

cryopreservation (P4N24 vs. P4N48), protein activation cascade was affected by cryopreservation and sub-culture for $24 \mathrm{~h}$ at $\mathrm{P} 4$ compared to non-cryopreserved and sub-cultured for $24 \mathrm{~h}$ (P4N24 vs. P4C24), regulation of smooth muscle cell proliferation was affected by longterm culture from P4 to P10 without cryopreservation (P4N48 vs. P10N48), cell proliferation and programmed cell death were affected by continuous culturing from $24 \mathrm{~h}$ to $48 \mathrm{~h}$ at P10 (P10N24 vs. P10N48), and cell communication and signal transduction were affected by post-thawing and sub-culturing for $24 \mathrm{~h}$ at $\mathrm{P} 4$ compared to non-cryopreservation at P10 (P10N24 vs. P10C24). In cellular component as shown in Fig. 5d, cytoskeleton and chromosome passenger complex were affected by continuous culture from $24 \mathrm{~h}$ to $48 \mathrm{~h}$ at P4 (P4N24 vs. P4N48), extracellular region and lysosome were affected by longterm culture from P4 to P10 without cryopreservation (P4N48 vs. P10N48), nuclear replication fork, lysosomal and endoplasmic reticulum lumen were affected by cryopreservation and sub-culture for $48 \mathrm{~h}$ at P10 compared to P4 (P4C48 vs. P10C48).

In order to further analyze the effect of cryopreservation on hUC-MSCs function, differential proteins enriched in biological processes of GO classification having known identities in MSCs functions. The functions of these differentially hUC-MSCs proteins are listed in Table 1, which are associated with differentiation, immunoregulation, wound healing and regeneration, apoptotic signaling pathway, oxidation resistance, cartilage development, regulation of cytokine production, cell migration and others. Specific protein information and the fold of change in different groups were shown in Table 2.

Protein domain was analyzed after cryopreservation and sub-culture for $24 \mathrm{~h}$ and $48 \mathrm{~h}$ at P4 and P10, respectively, compared with non-cryopreserved groups as shown in Fig. 5e. The results showed that immunoglobulin-like fold domain was affected by the continuous culture from $24 \mathrm{~h}$ to $48 \mathrm{~h}$ at $\mathrm{P} 4$ without cryopreservation (P4N24 vs. P4N48). BRICHOS domain and galactosebinding domain-like were affected by long-term culture from P4 to P10 without cryopreservation and sub-culture for $24 \mathrm{~h}$ (P4N24 vs. P10N24). Chemokine domain was affected by continuous culturing from by long-term culture from P4 to P10 without cryopreservation and sub-culture for $48 \mathrm{~h}$ (P4N48 vs. P10N48). Hydroxylase, iron-dependent dioxygenase, glycoside hydrolase 


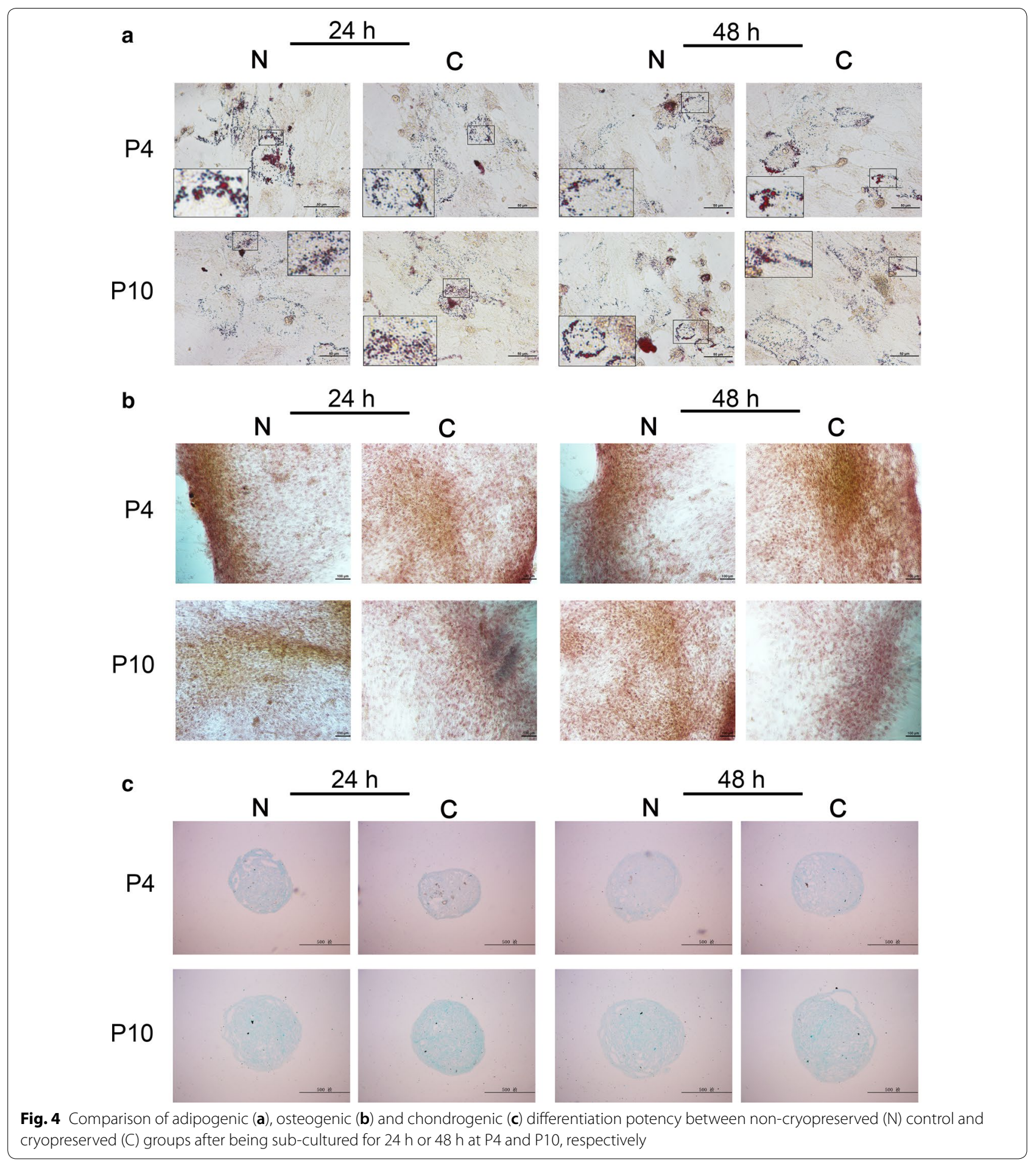

superfamily and thioredoxin-like fold domain were affected by cryopreservation and sub-culturing $48 \mathrm{~h}$ at P10 compared to P4 (P4C48 vs. P10C48).

In addition, differentially expressed proteins were also analyzed by KEGG (Kyoto Encyclopedia of Genes and Genomes) to show the network of pathway interactions (The raw data of differentially expressed proteins enriched in KEGG database as shown in Additional file 1: Table S1). The results as shown in Fig. 6a indicated that progesterone mediated oocyte maturation, complement 


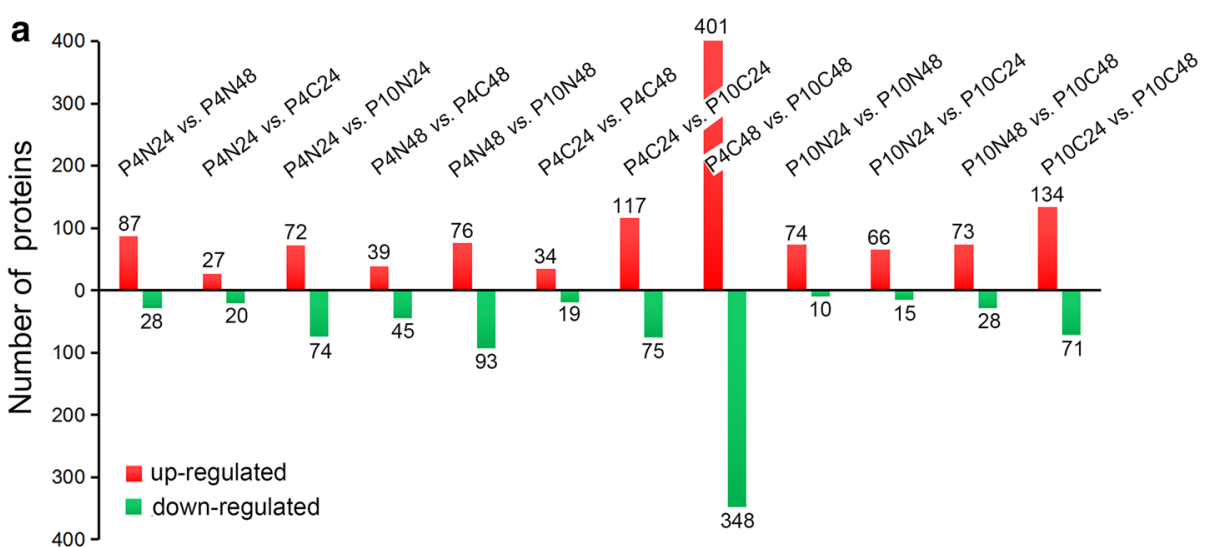

b
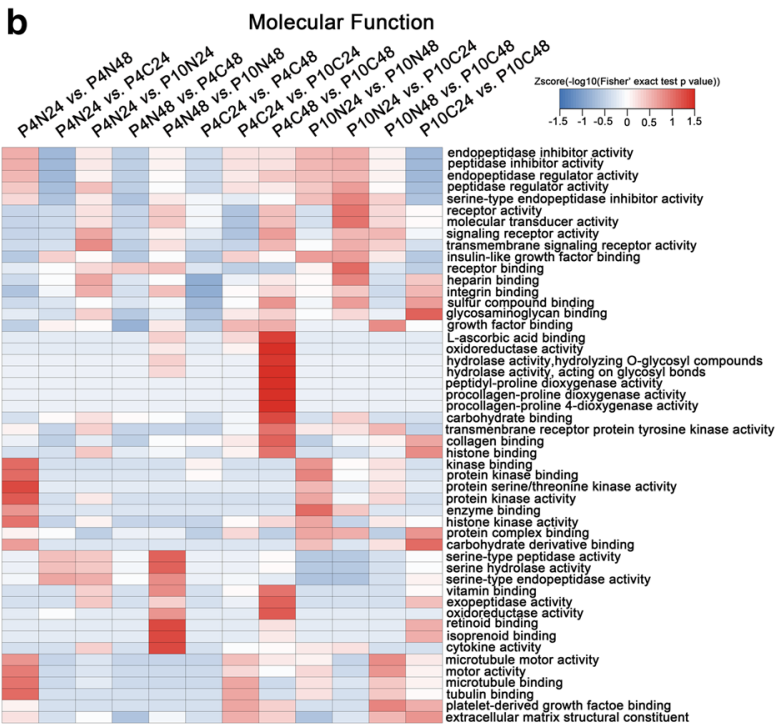

d
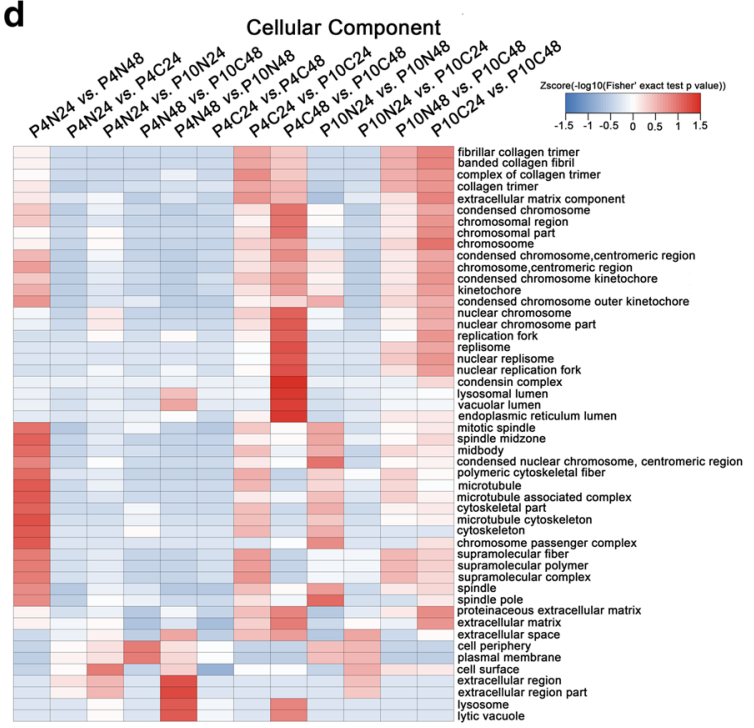

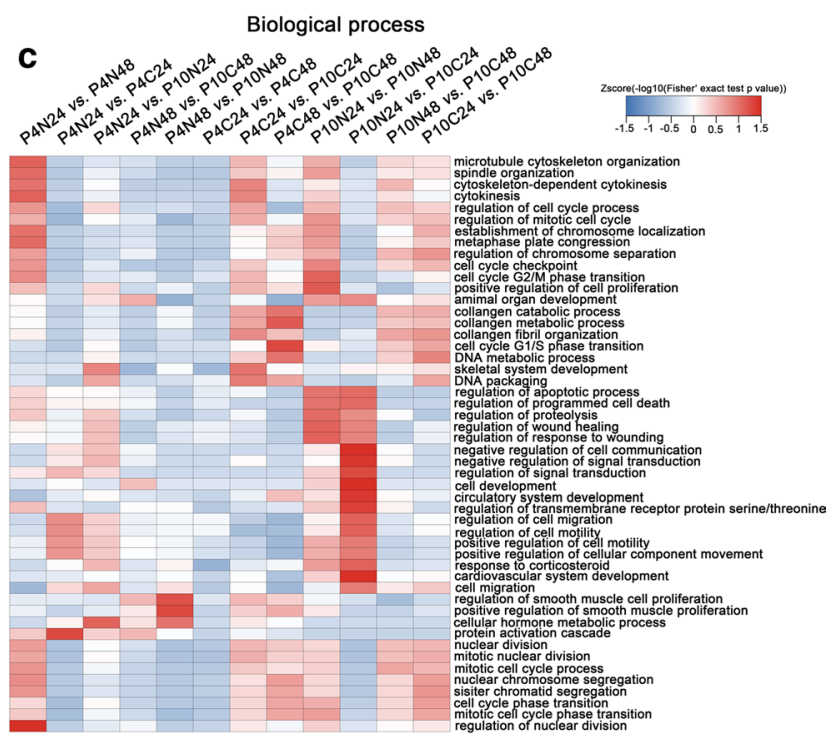

-

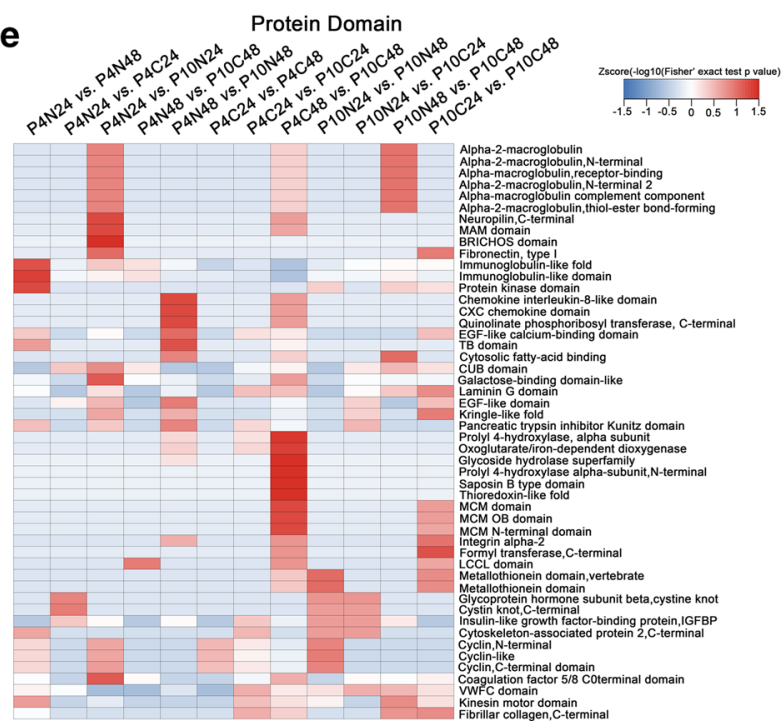

Fig. 5 The number and the GO heatmaps of differentially expressed proteins. a The histogram of differentially expressed proteins. The heatmap of differential proteins enriched pathways in molecular function (b), biological process (c), cellular component (d) and protein domain (e) 
Table 1 Biological processes classification of differential identified proteins in MSCs

\begin{tabular}{|c|c|}
\hline Biological processes & Gene name \\
\hline Differentiation & $\begin{array}{l}\text { GATA6, DKK1, STC1, PDGFRB, COL5A2, FST, CCNB1, AURKA, TOP2A, INHBA, COL1A1, ANLN, JUN, } \\
\text { SEMA7A, NCAM1, COL12A1, NRP2, FBN2, HGF }\end{array}$ \\
\hline Immune system regulation process & $\begin{array}{l}\text { TNFAIP3, KIF2C, PTX3, TMBIM1, IGHG1, JUN, NDRG1, NCAM1, MYO10, KIF22, COL1A1, RACGAP1, } \\
\text { SEMA7A, KIF11, INHBA, MT2A, FST, C3, GEM, TOP2A, SERPINE1, KIF23, ANLN, PDCD1LG2, CRISPLD2, } \\
\text { JUN }\end{array}$ \\
\hline Wound healing and regeneration & $\begin{array}{l}\text { TNFAIP3, SERPINB2, GATA6, MKI67, SERPINE1, F3, FOSL1, AURKA, COL1A1, DCN, NRP2, HGF, JUN, C3, } \\
\text { PDGFRB, CCNB1, TFPI2, HIST2H3A, CCNA2 }\end{array}$ \\
\hline Apoptotic signaling pathway & $\begin{array}{l}\text { BIRC5, STK17B, F3, TNFAIP3, SERPINE1, INHBA, TMBIM1, TIMP3, TOP2A, CHEK1, HGF, PDGFRB, TPX2, } \\
\text { GATA6, SERPINB2, AURKA, CCNB1, TNFAIP3, NUAK1, FOSL1, AURKB, CPEB4, PLK1, JUN, ARAF, AMIGO2 }\end{array}$ \\
\hline Myeloid cell differentiation and ossification & INHBA, FBN2, STC1, COL5A2, JUN, HGF, COL1A1, SEMA7A \\
\hline Oxidation resistance & $\begin{array}{l}\text { TNFAIP3, PTX3, NDRG1, TIMP3, SERPINE1, COL1A1, NDRG1, STK17B,AURKA, PLK1, PDGFRB, CPEB4, } \\
\text { AURKB, AMIGO2, TMBIM1, JUN, STC1, ARAF, GATA6, HGF, FOSL1, CCNB1, TOP2A, F3, CPEB4, BIRC5, } \\
\text { SERPINB2, INHBA, CCNA2 }\end{array}$ \\
\hline Adaptive immune response & $\begin{array}{l}\text { TNFAIP3, IGHG1, MYO10, DCN, C3, HGF, PDCD1LG2, JUN, SEMA7A, FST, INHBA, PTX3, TOP2A, SERPINE1, } \\
\text { NCAM1, ANLN, MT2A }\end{array}$ \\
\hline Inflammatory response & TNFAIP3, PTX3, SERPINE1, PDCD1LG2, SEMA7A, F3, HGF, C3 \\
\hline Interferon-gamma-mediated signaling pathway & PDCD1LG2, NCAM1, INHBA, MT2A \\
\hline Cartilage development & STC1, BNC2, LUM, COL1A1, STC1, COL1A1, MEX3C \\
\hline Regulation of cytokine production & GATA6, LUM, TNFAIP3, SERPINE1, PDCD1LG2, SEMA7A, INHBA, HGF, C3 \\
\hline Angiogenesis & SERPINE1, GATA6, PDGFRB, F3, JUN, HGF, NRP2, C3 \\
\hline Antigen processing and presentation & RACGAP1, TNFAIP3, CCNA2, KIF22, INHBA, KIF11, KIF2C, KIF23 \\
\hline Cell migration & F3, STC1, SERPINE1, SMURF2, DCN, COL1A1, PDGFRB, HGF, NRP2, JUN \\
\hline Transforming growth factor beta1 production & GATA6, COL1A1, C3, LUM, JUN, SERPINE1, TNFAIP3, PDCD1LG2, SEMA7A, HGF, INHBA \\
\hline Response to growth factor & $\begin{array}{l}\text { PDGFRB, GATA6, NRP2, DKK1, SHCBP1, SHCBP1, CCNA2, SMURF2, COL1A1, SMURF2, JUN, FBN2, HGF, } \\
\text { DCN, LUM }\end{array}$ \\
\hline Aging & CHEK1, SERPINE1, AURKB, PDGFRB, DCN, JUN \\
\hline Regulation of endothelial cell proliferation & SERPINE1, GATA6, DCN, TNFAIP3, THBS2, HGF, F3, C3, JUN, NRP2 \\
\hline
\end{tabular}

and coagulation cascades and protein digestion related pathways were affected by continuous culturing from $24 \mathrm{~h}$ to $48 \mathrm{~h}$ at P4 (P4N24 vs. P4N48) without cryopreservation. Retinol metabolism and vitamin absorption related pathways were affected by long-term culture from P4 to P10 without cryopreservation and sub-culture for $24 \mathrm{~h}$ (P4N24 vs. P10N24). Steroid hormone biosynthesis related pathways was effected by post-thawing and sub-culturing for $48 \mathrm{~h}$ compared to non-cryopreservation and sub-culture for $48 \mathrm{~h}$ at $\mathrm{P} 4$ (P4N48 vs. P4C48). Nicotinamide metabolism, antifolate resistance and staphylococcus aureus infection related pathways (Not contaminated) were affected by long-term culture from P4 to P10 without cryopreservation and sub-culture for 48 h (P4N48 vs. P10N48). Glycosaminoglycan degradation and DNA replication related pathways were affected by cryopreservation and sub-culture for $48 \mathrm{~h}$ at P10 compared to P4 (P4C48 vs. P10C48). In addition, the differentially expressed proteins of the enriched KEGG pathway were listed as Fig. 6b, the red and blue present up-regulaed and down-regulated proteins, respectively. These results indicated that the expression of hUC-MSCs proteins which are involved in many pathways were changed by cryopreservation as well as long-term culturing at $\mathrm{P} 4$ and $\mathrm{P} 10$.

\section{Verification of cryopreservation and long-term culture induced candidate proteins by PRM}

The differentially expressed proteins were separated into several categories according to their functions by GO and KEGG enrichment analysis, to validate the results of MS and to compare the influence mechanisms of cryopreservation and long-term culture on hUC-MSCs, we used PRM analysis to assess the abundance of 14 candidate proteins whole abundance changes in response to hUC-MSCs cryopreservation and long-term culture as determined by TMT. The 14 differentially expressed proteins as well as enriched various pathways were selected from 4 groups (P4N24 vs. P4C24, P4N24 vs. P10N24, $\mathrm{P} 4 \mathrm{C} 24$ vs. P10C24, P10N24 vs. P10C24) and involved in tdioxygenase activity, cell development, extracellular matrix, oxidoreductase activity, reproductive process, hydrolase activity, ATP binding, protein kinase activity, immune process, cell growth and division. As shown in Table 3, 14 proteins in PRM analysis was consistent with the results of TMT-based quantitation results. Although 
Table 2 Differential proteins associated with MSCs function

\begin{tabular}{|c|c|c|c|c|c|c|c|c|c|c|c|c|c|}
\hline $\begin{array}{c}\text { Protein } \\
\text { accession }\end{array}$ & Gene name & $\begin{array}{c}\text { P4N24 } \\
\text { vs. } \\
\text { P4N48 }\end{array}$ & $\begin{array}{l}\text { P4N24 } \\
\text { vs. } \\
\text { P4C24 }\end{array}$ & $\begin{array}{c}\text { P4N24 } \\
\text { vs. } \\
\text { P10N24 }\end{array}$ & $\begin{array}{c}\text { P4N48 } \\
\text { vs. } \\
\text { P4C48 }\end{array}$ & $\begin{array}{c}\text { P4N48 } \\
\text { vs. } \\
\text { P10N48 }\end{array}$ & $\begin{array}{c}\mathrm{P} 4 \mathrm{C} 24 \\
\text { vs. } \\
\mathrm{P} 10 \mathrm{C} 48\end{array}$ & $\begin{array}{c}\mathrm{P} 4 \mathrm{C} 24 \\
\text { vs. } \\
\mathrm{P} 10 \mathrm{C} 24\end{array}$ & $\begin{array}{c}\mathrm{P} 4 \mathrm{C} 48 \\
\text { vs. } \\
\mathrm{P} 10 \mathrm{C} 48\end{array}$ & $\begin{array}{c}\text { P10N24 } \\
\text { vs. } \\
\text { P10N48 }\end{array}$ & $\begin{array}{c}\mathrm{P} 10 \mathrm{~N} 24 \\
\text { vs. } \\
\mathrm{P} 10 \mathrm{C} 24\end{array}$ & $\begin{array}{c}\text { P10N48 } \\
\text { vs. } \\
\text { P10C48 }\end{array}$ & $\begin{array}{c}\mathrm{P} 10 \mathrm{C} 24 \\
\text { vs. } \\
\mathrm{P} 10 \mathrm{C} 48\end{array}$ \\
\hline Q86SJ2 & AMIGO2 & 0.671 & NS & NS & 1.422 & 1.377 & 0.749 & NS & NS & NS & NS & NS & NS \\
\hline Q9NQW6 & ANLN & 1.861 & NS & 1.363 & 0.741 & NS & NS & 1.711 & 2.167 & 1.620 & 1.335 & 1.354 & 1.642 \\
\hline P10398 & ARAF & 0.760 & NS & 0.766 & NS & NS & NS & NS & 0.741 & NS & NS & NS & NS \\
\hline O14965 & AURKA & 1.930 & NS & NS & NS & NS & NS & NS & NS & 1.725 & 1.429 & NS & NS \\
\hline Q96GD4 & AURKB & 1.592 & NS & 1.308 & NS & NS & NS & NS & NS & 1.398 & NS & NS & NS \\
\hline O15392 & BIRC5 & 1.612 & NS & NS & NS & NS & NS & 1.622 & 2.275 & 1.803 & NS & NS & 1.791 \\
\hline P01024 & C3 & 3.316 & 3.729 & 4.611 & 1.347 & 1.409 & NS & NS & 0.724 & NS & NS & 0.692 & NS \\
\hline P20248 & CCNA2 & 1.845 & NS & 1.324 & NS & NS & 1.369 & 1.408 & 1.689 & 1.545 & NS & NS & NS \\
\hline P14635 & CCNB1 & 1.751 & NS & 1.312 & 0.734 & NS & 1.488 & 1.864 & 2.181 & 1.631 & NS & NS & NS \\
\hline O14757 & CHEK1 & 1.331 & NS & NS & NS & NS & NS & 1.390 & 1.928 & NS & NS & 1.367 & 1.613 \\
\hline Q99715 & COL12A1 & 0.723 & NS & 0.706 & 1.459 & NS & NS & 0.714 & 0.508 & NS & NS & 0.766 & 0.585 \\
\hline P02452 & COL1A1 & 0.707 & NS & NS & NS & 1.302 & NS & 0.725 & 0.630 & NS & NS & 0.603 & 0.681 \\
\hline P05997 & COL5A2 & 0.768 & NS & NS & NS & NS & NS & 0.742 & 0.629 & NS & NS & 0.691 & 0.683 \\
\hline Q17RY0 & CPEB4 & 1.372 & NS & NS & NS & NS & NS & NS & NS & NS & NS & NS & NS \\
\hline Q9H0B8 & CRISPLD2 & 0.557 & NS & NS & 1.662 & NS & NS & NS & 0.537 & 0.608 & NS & NS & 0.638 \\
\hline P07585 & $\mathrm{DCN}$ & 0.760 & NS & NS & NS & NS & 0.744 & 0.619 & 0.520 & NS & NS & 0.715 & 0.626 \\
\hline O94907 & DKK1 & 1.584 & NS & 1.651 & 0.703 & 1.387 & NS & 1.806 & 2.744 & 1.331 & 1.387 & 1.391 & NS \\
\hline P13726 & F3 & 1.414 & 1.408 & 0.754 & NS & NS & NS & NS & 1.790 & 1.852 & 1.903 & NS & 1.369 \\
\hline P35556 & FBN2 & 0.762 & NS & NS & NS & NS & NS & NS & NS & NS & NS & NS & NS \\
\hline P15407 & FOSL1 & 1.775 & NS & NS & 0.753 & NS & NS & 1.736 & 1.619 & 1.494 & 1.643 & NS & NS \\
\hline P19883 & FST & 2.036 & NS & NS & 0.581 & NS & NS & 1.528 & 1.894 & 1.880 & 1.719 & NS & 1.452 \\
\hline Q92908 & GATA6 & 0.746 & NS & NS & & NS & 0.728 & NS & NS & NS & NS & NS & NS \\
\hline P55040 & GEM & 1.308 & NS & NS & 0.663 & NS & NS & 1.321 & 1.675 & 1.320 & NS & NS & NS \\
\hline P14210 & HGF & 0.767 & NS & NS & 1.453 & 1.448 & NS & NS & NS & NS & NS & NS & NS \\
\hline Q71DI3 & HIST2H3A & 1.445 & NS & 1.572 & NS & 1.333 & 1.339 & 1.500 & 1.809 & NS & NS & NS & 1.614 \\
\hline P01857 & IGHG1 & 2.704 & 2.998 & 4.018 & 1.524 & NS & 1.374 & 1.663 & NS & NS & NS & NS & NS \\
\hline P08476 & INHBA & 1.478 & NS & NS & NS & NS & NS & NS & NS & 1.373 & 1.592 & NS & NS \\
\hline P05412 & JUN & 1.350 & NS & NS & NS & 1.337 & NS & 1.718 & 1.584 & 1.467 & NS & NS & NS \\
\hline P52732 & KIF11 & 1.417 & NS & 1.313 & NS & NS & NS & 1.587 & 2.325 & 1.307 & NS & 1.496 & 1.794 \\
\hline Q14807 & KIF22 & 1.413 & NS & NS & NS & NS & NS & NS & 1.433 & 1.311 & NS & NS & NS \\
\hline Q02241 & KIF23 & 1.417 & NS & NS & NS & NS & NS & 1.590 & 2.307 & NS & NS & 1.753 & NS \\
\hline Q99661 & KIF2C & 1.435 & NS & NS & NS & NS & NS & 1.449 & 2.158 & NS & NS & 1.499 & 1.828 \\
\hline P51884 & LUM & 0.627 & NS & NS & NS & NS & 0.572 & 0.538 & NS & NS & NS & NS & 0.722 \\
\hline Q5U5Q3 & MEX3C & 0.769 & NS & NS & NS & NS & NS & NS & NS & 0.768 & 0.746 & NS & NS \\
\hline P46013 & MKI67 & 1.458 & NS & 1.473 & 0.760 & NS & NS & 1.694 & 2.337 & NS & NS & 1.452 & 1.715 \\
\hline P02795 & MT2A & 1.383 & 0.732 & NS & 0.701 & NS & 1.324 & NS & 2.449 & 1.650 & NS & 1.693 & 2.624 \\
\hline Q9HD67 & MYO10 & 1.300 & NS & NS & NS & NS & NS & NS & NS & 1.402 & NS & NS & NS \\
\hline P13591 & NCAM1 & 0.747 & NS & NS & NS & 1.424 & NS & NS & NS & NS & NS & NS & NS \\
\hline
\end{tabular}


Table 2 (continued)

\begin{tabular}{|c|c|c|c|c|c|c|c|c|c|c|c|c|c|}
\hline Q92597 & NDRG1 & 1.450 & NS & NS & NS & NS & 1.462 & NS & NS & NS & NS & NS & NS \\
\hline O60462 & NRP2 & 0.655 & NS & 0.632 & 1.464 & NS & NS & NS & 0.638 & NS & NS & NS & NS \\
\hline O60285 & NUAK1 & 0.730 & NS & NS & NS & NS & NS & NS & 0.751 & NS & NS & NS & NS \\
\hline Q9BQ51 & PDCD1LG2 & 1.534 & 1.350 & NS & NS & NS & NS & NS & NS & 1.339 & NS & 1.534 & NS \\
\hline P09619 & PDGFRB & 0.700 & NS & NS & NS & NS & NS & NS & NS & NS & NS & NS & NS \\
\hline P53350 & PLK1 & 1.617 & NS & NS & NS & NS & NS & 1.677 & 1.819 & 1.450 & NS & NS & 1.407 \\
\hline P26022 & PTX3 & 1.354 & 1.313 & NS & 0.672 & NS & 0.693 & NS & 1.699 & 1.357 & 1.432 & NS & NS \\
\hline Q9H0H5 & RACGAP1 & 1.392 & NS & NS & NS & NS & NS & 1.501 & 2.203 & NS & NS & 1.626 & 1.747 \\
\hline O75326 & SEMA7A & 1.647 & NS & NS & 0.740 & NS & NS & 1.701 & 1.792 & 1.618 & 1.638 & NS & NS \\
\hline P05120 & SERPINB2 & 1.505 & NS & NS & 0.736 & NS & NS & NS & NS & 1.309 & NS & NS & NS \\
\hline P05121 & SERPINE1 & 1.686 & NS & NS & NS & NS & NS & NS & NS & 1.595 & 1.730 & NS & NS \\
\hline P52823 & STC1 & 1.794 & NS & 0.556 & NS & 0.647 & 1.734 & NS & NS & 2.088 & 2.108 & NS & NS \\
\hline O94768 & STK17B & 1.343 & NS & NS & NS & NS & NS & NS & NS & 1.582 & 1.571 & NS & NS \\
\hline P48307 & TFPI2 & 1.731 & NS & 0.655 & NS & 0.526 & 1.491 & NS & NS & 1.391 & 1.981 & 1.780 & NS \\
\hline P35442 & THBS2 & 0.731 & NS & NS & NS & NS & NS & 0.768 & 0.694 & NS & NS & NS & 0.706 \\
\hline P35625 & TIMP3 & 1.529 & NS & 0.730 & NS & NS & NS & 1.428 & 1.336 & 1.730 & 1.850 & NS & NS \\
\hline Q969X1 & TMBIM1 & 1.602 & NS & NS & NS & NS & NS & NS & NS & NS & NS & NS & NS \\
\hline P21580 & TNFAIP3 & 1.494 & NS & NS & NS & NS & 1.357 & 1.327 & NS & NS & NS & NS & NS \\
\hline P11388 & TOP2A & 1.782 & NS & NS & 0.733 & NS & 1.439 & 1.584 & 2.334 & 1.679 & NS & 1.407 & 2.119 \\
\hline Q9ULW0 & TPX2 & 1.663 & NS & NS & 0.758 & NS & NS & 1.393 & 1.778 & 1.517 & NS & NS & 1.495 \\
\hline
\end{tabular}

Red is up-regulation and blue is down-regulation, NS is no significant difference

the fold changes of SMTN in P4C24/P10C24, SEMA7A in P4C24/P10C24 and P10N24/P10C24 analyzed by PRM more than TMT, whereas the TMT and PRM results all showed a rising trend. Our PRM results were in consistent with the data from TMT analysis (Table 3), which further confirmed the credibility of the proteomics data.

\section{Discussion}

Human umbilical cord-derived MSCs are promising seeding cells in cell therapy and regenerative medicine due to their unique advantages. Cryopreservation plays an important role in the maintenance of MSCs function and avoids adverse effects caused by long-term culture [19]. DMSO is a widely used penetrating cryoprotectant for MSCs cryopreservation when using the conventional slow freezing protocol. Although efforts for the reduction of DMSO concentrations have been made to alleviate the adverse reactions of DMSO and decreased DMSO concentration (as low as $2 \%$ combined with other cryoprotectants) has been successfully employed [20], the viability of MSCs cannot be guaranteed. In addition, the combination of multiple penetrating cryoprotectants is not conducive to understand the adverse mechanisms of each cryoprotectant on cell recovery or engraftment. In our previous study, DMSO and ethylene glycol (EG) have been used for vitrification of MSCs, and the results showed that the viability of cells vitrified by DMSO is less than those by EG. However, the transcripts of larger numbers of genes affected by EG are much more than those by DMSO [13]. Therefore, the method of conventional slow freezing method by using $10 \%$ DMSO was selected in the present study and it is still the most widely used method at present $[16,17]$. In regard to the store period $(24 \mathrm{~h})$ of MSCs in liquid nitrogen, whether long-term storage more than $24 \mathrm{~h}$ will have more profound effects remains need to be further studied [13].

In this present study, the conventional slow freezing method using $10 \%$ DMSO was used for MSC cryopreservation. The freezing and thawing process decrease the viability of cells either at P4 $(94.42 \pm 1.53 \%)$ or P10 $(93.82 \pm 2.13 \%)$. In previous studies, Fong et al. reported that hUC-MSCs viability was $85-90 \%$ after thawing by using the same slow cooling method [21], and Woods et al. reported the post-thaw viability of human MSCs was about $91 \%$ by using $1.0 \mathrm{M}$ (about $7.1 \%, w / v$ ) and $1.5 \mathrm{M}$ (about $10.65 \%, w / v$ ) DMSO freezing with this method [22]. Our results showed similar viabilities compared to the previous studies. Although the conventional slow freezing method has been widely used and can also 


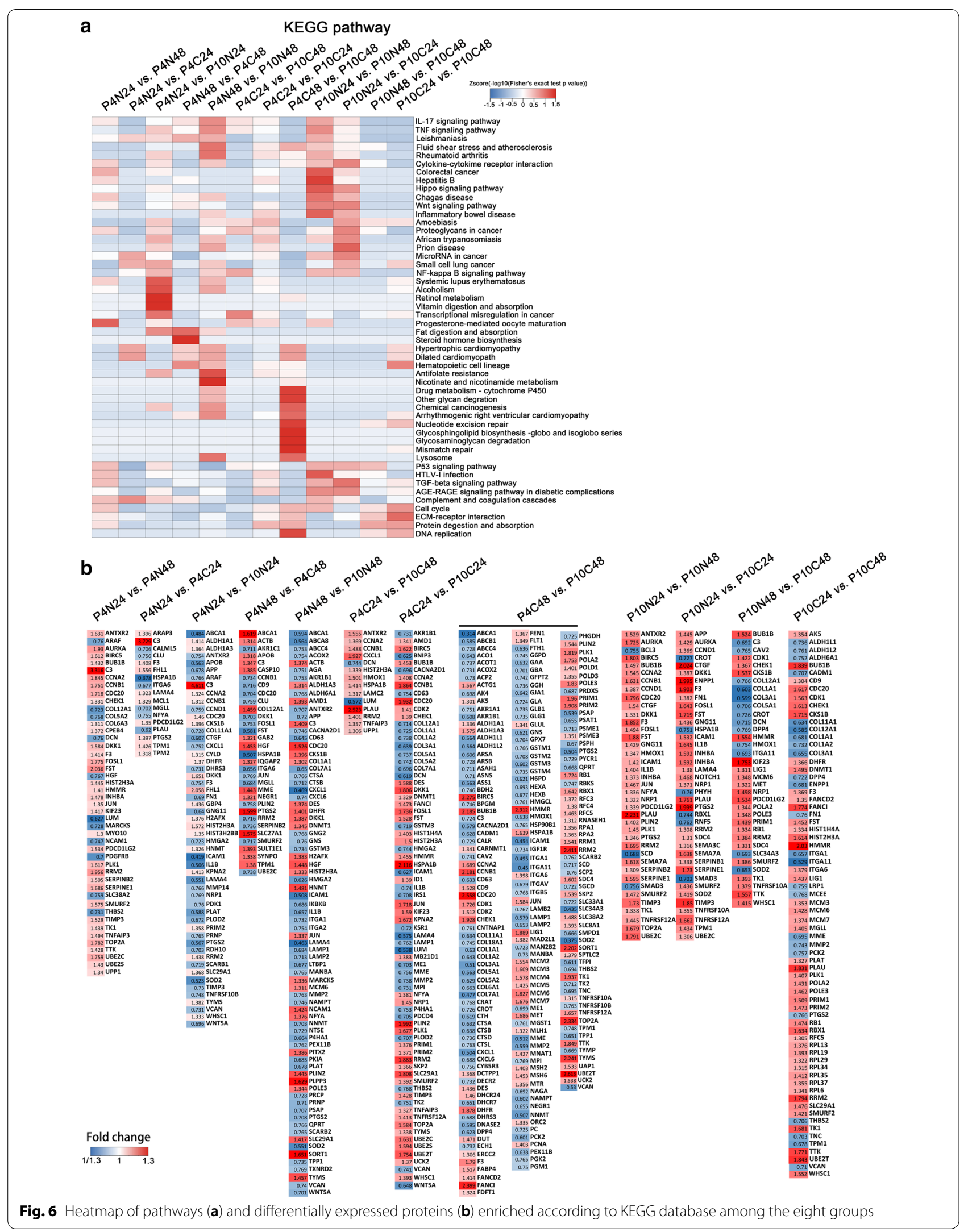


Table 3 Comparison of the quantification results between TMT and PRM of the 14 candidate different expression proteins

\begin{tabular}{|c|c|c|c|c|c|c|c|c|c|c|}
\hline \multirow[t]{2}{*}{ Protein accession } & \multirow[t]{2}{*}{ Proteins } & \multirow[t]{2}{*}{ Signature peptides } & \multicolumn{2}{|c|}{$\begin{array}{l}\text { P4N24/ } \\
\text { P4C24 }\end{array}$} & \multicolumn{2}{|c|}{$\begin{array}{l}\text { P4N24/ } \\
\text { P10N24 }\end{array}$} & \multicolumn{2}{|c|}{$\begin{array}{l}\text { P4C24/ } \\
\text { P10C24 }\end{array}$} & \multicolumn{2}{|c|}{$\begin{array}{l}\text { P10N24/ } \\
\text { P10C24 }\end{array}$} \\
\hline & & & TMT & PRM & TMT & PRM & TMT & PRM & TMT & PRM \\
\hline Q8IVL6 & $\mathrm{P} 3 \mathrm{H} 3$ & DLETPPHWAAYDTGLELLGR & 1.03 & 1.17 & 0.96 & 1.06 & 0.91 & 0.86 & 0.98 & 0.96 \\
\hline P53814 & SMTN & AQEIEAATLAGRLQDGTPQAALSPLTPAR & 1.04 & 1.04 & 1.23 & 1.27 & 1.92 & 3.29 & 1.63 & 2.68 \\
\hline Q96CG8 & CTHRC1 & QCSWSSLNYGIDLGKVLFSGSLR & 1.47 & 2.08 & 0.89 & 0.81 & 0.61 & 0.39 & 1.01 & 1.00 \\
\hline O75326 & SEMA7A & DPYCGWDQGR & 1.06 & 1.09 & 1.10 & 1.08 & 1.70 & 3.03 & 1.64 & 3.08 \\
\hline P35354 & PTGS2 & SHLIDSPPTYNADYGYKSGLDDINPTVLLK & 1.40 & 2.79 & 0.57 & 0.50 & 0.81 & 0.53 & 2.00 & 2.99 \\
\hline Q9NQW6 & ANLN & LLLIATGKGFLTIFEDVSGFGAWHR & 1.06 & 1.08 & 1.36 & 1.32 & 1.71 & 2.44 & 1.34 & 1.99 \\
\hline P58335 & ANTXR2 & VSPVGETYIHEGLKLDALWALLR & 0.87 & 0.97 & 0.75 & 0.70 & 1.18 & 1.17 & 1.36 & 1.63 \\
\hline P48307 & TFPI2 & LQVSVDDQCEGSTEKTCDAFTYTGCGGNDNNFVSR & 1.08 & 0.96 & 0.66 & 0.47 & 1.20 & 1.23 & 1.98 & 2.51 \\
\hline Q13642 & FHL1 & FWHDTCFR & 1.56 & 1.45 & 2.06 & 2.00 & 1.69 & 2.53 & 1.28 & 1.84 \\
\hline Q02241 & KIF23 & ALLQEFDNAVLSK & 0.96 & 1.05 & 1.29 & 1.49 & 1.59 & 1.82 & 1.18 & 1.28 \\
\hline Q9HOH5 & RACGAP1 & SIGSAVDQGNESIVAK & 0.97 & 0.87 & 1.25 & 1.56 & 1.50 & 2.47 & 1.17 & 1.38 \\
\hline P53350 & PLK1 & LILYNDGDSLQYIER & 0.96 & 1.01 & 1.27 & 1.89 & 1.68 & 2.70 & 1.27 & 1.44 \\
\hline P00749 & PLAU & FEVENLILHK & 0.62 & 0.42 & 0.43 & 0.27 & 1.23 & 1.50 & 1.76 & 2.30 \\
\hline 000762 & UBE2C & GISAFPESDNLFKLSLEFPSGYPYNAPTVK & 1.02 & 1.05 & 1.27 & 1.52 & 1.63 & 2.06 & 1.31 & 1.42 \\
\hline
\end{tabular}

obtain better viability, profound influence of the freezing process and cryoprotectant on the transcript and protein function of hUC-MSCs remains unknown.

Conventionally, the morphology, surface marker expression and tri-lineage differentiation potency are regarded as a "gold standard" for identifying MSCs according to the International Society for Cellular Therapy. In this study, there are no significant differences between non-cryopreserved and post-thaw following sub-culture 24 or $48 \mathrm{~h}$ in morphology, surface markers and tri-lineage differentiation potency at $\mathrm{P} 4$ and P10. Hence, these results concluded that cryopreservation and long-term culture did not affect the characteristics of hUC-MSCs, which are consistent with previous studies $[13,23]$. To our knowledge, almost all of the studies have shown that cryopreservation does not affect the morphology, surface markers and differentiation potency as description in a review [24] and proven by our previous [13] and present study. However, our previous study revealed that though the morphology, surface markers and tri-lineage differentiation potency of MSCs were not affected by cryopreservation, the global gene expression was affected either vitrified with DMSO or EG as a cryoprotectant [13]. In the present study, many protein's expression was affected by cryopreservation and long-term culture revealed by the proteomics analysis. A total of 47 and 81 proteins expressed were affected by freezing and thawing at P4 (P4N24 vs. P4C24) and P10 (P10N24 vs. P10C24), respectively, as well as cell communication and signal transduction were obviously affected though GO analysis. Therefore, in our opinion, the traditional identification standards based on qualitative detection (post thaw viability, morphology, surface markers and tri-lineage differentiation potency) may be insufficient for the evaluation of the change of biological characteristics after cryopreservation or environmental stimulus during long-term culture. Therefore, it is necessary to explore quantitative methods for MSCs quality evaluation such as a protein targeting quantification method in preclinical or clinical application.

Previous studies have reported that cryopreservation can affect the immunomodulatory properties of MSCs, and the levels of heat shock proteins increased and the inflammatory response was impaired within $24 \mathrm{~h}$ after thawing. However, these studies considered that the function of MSCs would be completely recovered after $24 \mathrm{~h}$ of culturing [25-27]. The protein expression recovery of cryopreserved MSCs is essential to maintain their properties after transplantation in vivo. In this present study, the proteomics profile showed that the 47 and 81 proteins of hUC-MSCs were affected by freeze-thawing and a $24 \mathrm{~h}$ sub-culture at $\mathrm{P} 4$ and $\mathrm{P} 10$, respectively. In this study, two time points ( 24 and $48 \mathrm{~h}$ ) were chose in this study because over-time culture can induce over-confluency of hUC-MSCs that is not conducive to evaluate the status of cells, and hUC-MSC passage with fresh culture medium contains serum can affect many proteins expression, which may not reflect the true status of cells after thawing [28]. In P4, the different proteins were enriched in microRNA in cancer, small cell lung cancer, hypertrophic cardiomyopathy and dilated cardiomyopathy due to the proteins such as TIMP3 (Metalloproteinase 
inhibitor 3), ITGA6 (Integrin alpha-6) and TPMs (Tropomyosins) were affected by culturing from $24 \mathrm{~h}$ to $48 \mathrm{~h}$ (P4N24 vs. P4N48) and freeze-thawing for culturing $24 \mathrm{~h}$ (P4N24 vs. P4C24), and these gene were clustered in pathway of those disease. TIMP3, ITGA6 and TPM are involved in the extracellular matrix, cytoskeleton and cell adhesion that directly related to the cellular regular function, and these genes change may be caused by cryopreservation or cryoprotectant, and cryopreservation could affect surface adhesion molecules had been reported [29]. It is indicated that TIMP3, ITGA6 and TPM may be good markers to detecting impairment of cell function which is still need to be further studied. Many studies have shown that extracellular matrix, cytoskeleton and cell adhesion are connected with lung cancer and cardiomyopathy. TIMP-3 inhibits the activity of metalloproteinases that play important roles in development and progression of lung tumors [30]. TIMP-3 is up-expressed in cardiac fibroblasts and cardiomyocytes but down-expressed in the failing heart [31]. Early studies have reported that ITGA6 is involved in the occurrence and development of lung cancer [32]. It is reported that ITGA6 corresponds to the activation of regeneration involving an epithelial-mesenchymal transition in adult heart [33]. TPM is a potential marker in lung cancer diagnosis [34], and the latest study showed TPM pseudophosphorylation results in dilated cardiomyopathy [35]. However, the relationship between cryopreservation of hUC-MSCs after long-term culture and diseases including cancer and cardiomyopathy remains unknown and need to be further studied.

The complement and coagulation cascades were alleviated by sub-culturing from $24 \mathrm{~h}$ to $48 \mathrm{~h}$ after freezethawing compared with the non-cryopreserved group with a sub-culture for $24 \mathrm{~h}$ or $48 \mathrm{~h}$ parallelly. Meanwhile, the proteins of fat digestion and absorption, steroid hormone biosynthesis, and hematopoietic cell lineage pathways were affected (P4N24 vs. P4C24 and P4N48 vs. P4C48). In P10, many pathways including cytokinecytokine receptor interaction, hippo signaling pathway, wnt signaling pathway, microRNA in cancer, small cell lung cancer, NF-kappa B signaling pathway and others were significantly alleviated by sub-culturing from $24 \mathrm{~h}$ to $48 \mathrm{~h}$ after freeze-thawing (P10N24 vs. P10C24 and P10N48 vs. P10C48). These results indicated that the effect of cryopreservation on the protein expression of MSCs at P10 was greater than those at P4. For example, related proteins of complement and coagulation cascades including CLU (Clustering), PLAU(Urokinase-type plasminogen activator), C3 (Complement C3) and F3(Tissue factor) were not recovered until a sub-culture to $48 \mathrm{~h}$ at $\mathrm{P} 4$, and related proteins of Th17 cell differentiation IL-1B and SMAD3 were not recovered until a sub-culture to
$48 \mathrm{~h}$ at $\mathrm{P} 10$, it maybe that serum or nutritional components for hUC-MSCs growth was less with consumption, and this would cause interference in the expression of a variety of proteins $[28,36]$. These results suggest that properly prolonging the time of continuous culture after freeze-thawing can alleviate the effect of cryopreservation on the change of proteins expression. In addition, rare studies have reported that cryopreservation reduces the homing/engraftment potential of MSCs by poor binding to the extracellular matrix such as fibronectin and the immunosuppression ability of MSCs play an important role in MSCs homing/engraftment. However, the knowledge about the recovery status of the main immunoregulation proteins of MSCs after cryopreservation and sub-culture is poor [27, 37].Therefore, it is necessary to sub-culture and recover the functional proteins of hUC-MSCs after cryopreservation and before transplantation, and the optimal recovery methods for MSCs are still need to be further explored.

The proliferation of MSCs is limited during long-term culture and the MSCs exhibit a aberrant phenotype of irregular flattened geometry and enlarged size [38]. Yang et al. found human bone marrow-derived MSCs undergo senescence during extensive passage and result in morphological, phenotypic and genetic changes from $\mathrm{P} 4$ to P8 [38]. De Witte et al. reported that long-term expansion induced aging of hUC-MSCs exhibiting stable phenotype but reduced immunosuppressive properties from P4 to P12 [39]. Facchin et al. reported that umbilical cord Wharton's Jelly-derived MSCs showed higher antioxidant ability to senescence than human adipose tissue-derived MSCs at high subculture passages, and they considered that the age of tissue donors is likely to be the main cause of senescence [40]. Moreover, recently, studies found that transcriptome and epigenetic regulations changes of hUC-MSCs occurred during long-term expansion [41, 42]. These studies not only indicated that long-term culture and expansion induces aging of hUC-MSCs as well as genes expression changed, but also suggested that the antioxidant ability of hUC-MSC is superior to others that were derived from human adult such as bone marrow and adipose tissue. In this present study, the morphology, surface markers expression, tri-lineage differentiation potency and proteomic analysis of hUC-MSCs were evaluated after long-term culturing and expanding from P4 to P10, and the results showed that the morphology, surface markers and differentiation potency were not affected but large scale of proteins were changed from $\mathrm{P} 4$ to $\mathrm{P} 10$, which involve in proteins related to cell cycle and P53 pathways including CCNB1(G2/mitoticspecific cyclin-B1), CCND1(G1/S-specific cyclinD1), CHEK1 (Serine/threonine-protein kinase Chk1), RRM2(Ribonucleoside-diphosphate reductase subunit 
M2), SERPINE1(Plasminogen activator inhibitor 1) and P53 pathway has been reported to relate to aging of MSCs in previous studies [6, 43, 44]. Superoxide dismutase 2 (SOD2) has been reported to participate in the aging of MSCs [45, 46]. In the present study, superoxide dismutase 2 (SOD2) is up-regulated in MSCs at P10 compare to those at $\mathrm{P} 4$, which indicated that oxidative stress may be activated.

The identified differential proteins of hUC-MSCs cryopreserved and thawed at P4 and P10 were enriched in the biological processes pathways of GO classification including differentiation, immunoregulation, wound healing and regeneration, apoptotic signaling pathway, oxidation resistance, cartilage development, regulation of cytokine production, cell migration, aging and others as shown in Table 1, and some proteins were enriched and appeared multiple times in various signaling pathways of hUC-MSCs biological processes including STC1 (Stanniocalcin-1), TNFAIP3 (Tumor necrosis factor alpha-induced protein 3), SERPINE1, COL1A1 (Collagen alpha-1(I)), PDGFR (Platelet-derived growth factor receptor), NCAM1 (Neural cell adhesion molecule 1), C3, JUN (Transcription factor AP-1), GATA6 (Transcription factor GATA-6), HGF (Hepatocyte growth factor), F3 and other proteins likely be used as markers to evaluate hUC-MSCs after cryopreserving and long-term culturing. MSCs can secrete STC1 to protect cancer cells from apoptosis by reducing reactive oxygen radical (ROS), it suggests that STC1 play an important role in antioxidant activity of MSCs [47]. The deficiency of TNFAIP3 in MSCs can induce immune thrombocytopenia and influence megakaryocytic differentiation through terminating the NF- $\mathrm{kB}$ pathway that suggests TNFAIP3 play a critical role in the process of MSCs alleviate $\mathrm{s}$ autoimmune disease [48]. The mutation of COL1A1 and COL1A2 in MSCs could cause osteogenesis imperfecta, it likely that COL1A1 and COL1A2 play an important role in osteogenesis differentiation from MSCs [49]. PDGFR signaling is emerging as a critical regulatory mechanism and important therapeutic target that critically directs the fate of mesenchymal stem cells during postnatal neovascularization [50]. It is reported that JUN not only can regulate human bone marrow MSCs differentiates into neuron-like cells and acilitates neurite outgrowth, but also play a key role in human MSCs aging and therapeutic potency maintaining $[51,52]$. C3 was secreted from MSCs that has an important role in the immunomodulatory and liver regeneration [53, 54]. HGF may have an important role in MSC recruitment sites of tissue regeneration, and may be beneficial in tissue engineering and cell therapy employing hMSCs [55]. These proteins such as STC1, TNFAIP3, SERPINE1, COL1A1, PDGFR, C3, JUN and HGF present important roles in maintaining
MSCs function, and CHEK1, SERPINE1, PDGFRB and JUN were also enriched in aging pathway of MSCs biological process. Therefore, these proteins may be used as indicators for the detection of MSCs after cryopreservation and long-term culturing. However, whether these proteins can be used as markers in clinical detection remains to be further studied.

\section{Conclusion}

The morphology, surface markers and tri-lineage differentiation potential of $\mathrm{P} 4$ and $\mathrm{P} 10$ hUC-MSCs were tested after cryopreservation and a sub-culturing for $24 \mathrm{~h}$ and $48 \mathrm{~h}$ which was compared with non-cryopreservation and sub-culturing $24 \mathrm{~h}$ and $48 \mathrm{~h}$, and the results showed no obvious differences among these groups. However, the proteomics analysis found that cryopreservation leads to changes in a large number of proteins expression compared to those of the controls. This report is the first to show the different effects of freeze-thaw and long-term culture on the proteome of hUC-MSCs. These results will be beneficial to understand the biological process involved in the cryopreservation and long-term culture of hUC-MSCs and contribute to improved cryopreservation protocols that maintain proteomic identity for clinical research, and promote scientists' attention to the recovery of main proteins and MSCs function after cryopreservation. This will also provide a foundation for safety detection and standardization guide of hUC-MSCs applications in clinical.

\section{Supplementary information}

Supplementary information accompanies this paper at https://doi. org/10.1186/s12014-020-09279-6.

Additional file 1: Table S1. The raw data of pathways and differentially expressed proteins enriched in KEGG database among the eight groups.

\section{Abbreviations}

hUC-MSCs: Human umbilical cord-derived mesenchymal stem cells; KEGG: Kyoto Encyclopedia of Genes and Genomes; DMSO: Dimethyl sulfoxide; GO: Gene Ontology; iTRAQ: Isobaric tags for relative and absolute quantification; TMT:Tandem mass tags; PRM: Parallel reaction monitoring; P4N24: Noncryopreserved and sub-cultured for $24 \mathrm{~h}$ at P4; P4C24: Cryopreserved and subcultured for $24 \mathrm{~h}$ at P4; P4N48: Non-cryopreserved and sub-cultured for $48 \mathrm{~h}$ at P4; P4C48: Cryopreserved and sub-cultured for $48 \mathrm{~h}$ at P4; P10N24: Noncryopreserved and sub-cultured for $24 \mathrm{~h}$ at P10; P10C24: Cryopreserved and sub-cultured for $24 \mathrm{~h}$ at P10; P10N48: Non-cryopreserved and sub-cultured for $48 \mathrm{~h}$ at P10; P10C48: Cryopreserved and sub-cultured for $48 \mathrm{~h}$ at P10.

\section{Acknowledgements}

The authors would like to thank Open Foundation of State Key Laboratory of Environmental Chemistry and Ecotoxicology, Research Center for Eco-Environmental Sciences, Chinese Academy of Sciences.

\section{Authors' contributions}

$X F, X P$ and $W S$ wrote the manuscript. $X F, B M I$ and $W S$ revised the manuscript. $B X, X D, X Y$ and $Y Y$ analysed the data. $X F$ and WS designed the experiment. BX, 
SL, HM and HW operated experiment. All authors read and approved the final manuscript.

\section{Funding}

This work was supported by grants from the National Natural Science Foundation of China (Grant Nos. 81960270, 31872973, 31560329), Major Science and Technology Projects of Yunnan Province (2018ZF007-05), National Key Research and Development Program of China (Grant No. 2016YFA0101403), Key Research and Development Program of Ningxia (Grant No. 2019BFG02007).

\section{Availability of data and materials \\ All data generated or analyzed during this study are included in this article.}

\section{Ethics approval and consent to participate}

The study was approved by the Ethics Review Board of Ningxia Medical University and General Hospital of Ningxia Medical University. Informed consent for participation was obtained from all subjects.

\section{Consent for publication}

Not applicable.

\section{Competing interests}

The authors declare that they have no competing interests.

\section{Author details}

${ }^{1}$ Key Laboratory of Fertility Preservation and Maintenance of Ministry of Education, Ningxia Medical University, Yinchuan 750004, China. ${ }^{2}$ Yunnan Key Laboratory of Primate Biomedical Research, Institute of Primate Translational Medicine, Kunming University of Science and Technology, Kunming 650500, China. ${ }^{3}$ Department of Obstetrics, The First People's Hospital of Yunnan Province, Kunming 650032, China.

Received: 6 November 2019 Accepted: 15 May 2020

Published online: 24 May 2020

\section{References}

1. Sierra Parraga JM, Rozenberg K, Eijken M, Leuvenink HG, Hunter J, Merino A, Moers C, Møller BK, Ploeg RJ, Baan CC, Jespersen B, Hoogduijn MJ. Effects of normothermic machine perfusion conditions on mesenchymal stromal cells. Front Immunol. 2019;10:765.

2. Fossett $E$, Khan WS. Optimising human mesenchymal stem cell numbers for clinical application: a literature review. Stem Cells Int. 2012;1:465259.

3. Friedenstein AJ, Piatetzky-Shapiro II, Petrakova KV. Osteogenesis in transplants of bone marrow cells. J Embryol Exp Morphol. 1966;16(3):381-90.

4. Han YF, Tao R, Sun TJ, Chai JK, Xu G, Liu J. Optimization of human umbilical cord mesenchymal stem cell isolation and culture methods. Cytotechnology. 2013;65(5):819-27.

5. Salehinejad P, Alitheen NB, Ali AM, Omar AR, Mohit M, Janzamin E, Samani FS, Torshizi Z, Nematollahi-Mahani SN. Comparison of different methods for the isolation of mesenchymal stem cells from human umbilical cord Wharton's jelly. Vitro Cell Dev Biol Anim. 2012;48(2):75-83.

6. Li H, Fan X, Kovi RC, Jo Y, Moquin B, Konz R, Stoicov C, Kurt-Jones E, Grossman SR, Lyle S, Rogers AB, Montrose M, Houghton J. Spontaneous expression of embryonic factors and p53 point mutations in aged mesenchymal stem cells: a model of age-related tumorigenesis in mice. Cancer Res. 2007:67(22):10889-98.

7. Stab BR, Martinez L, Grismaldo A, Lerma A, Gutiérrez ML, Barrera LA, Sutachan JJ, Albarracín SL. Mitochondrial functional changes characterization in young and senescent human adipose derived MSCs. Front Aging Neurosci. 2016;8:299.

8. Roobrouck VD, Ulloa-Montoya F, Verfaillie CM. Self-renewal and differentiation capacity of young and aged stem cells. Exp Cell Res. 2008;314(9):1937-44.

9. Le Blanc K, Tammik L, Sundberg B, Haynesworth SE, Ringdén O. Mesenchymal stem cells inhibit and stimulate mixed lymphocyte cultures and mitogenic responses independently of the major histocompatibility complex. Scand J Immunol. 2003;57(1):11-20.
10. Si YL, Zhao YL, Hao HJ, Fu XB, Han WD. MSCs: biological characteristics, clinical applications and their outstanding concerns. Ageing Res Rev. 2011:10(1):93-103.

11. Baxter MA, Wynn RF, Jowitt SN, Wraith JE, Fairbairn $L$, Bellantuono I. Study of telomere length reveals rapid aging of human marrow stromal cells following in vitro expansion. Stem Cells. 2004;22(5):675-82.

12. Hunt CJ. Cryopreservation of human stem cells for clinical application: a review. Transfus Med Hemother. 2011;38(2):107-23.

13. Fu X, Yan Y, Li S, Wang J, Jiang B, Wang H, Duan Y, Tan T, Gao F, Gong D, Niu Y, Ji W, Zheng B, Si W. Vitrification of rhesus macaque mesenchymal stem cells and the effects on global gene expression. Stem Cells Int. 2017:2017:3893691.

14. Jiang B, Yan L, Miao Z, Li E, Wong KH, Xu RH. Spheroidal formation preserves human stem cells for prolonged time under ambient conditions for facile storage and transportation. Biomaterials. 2017;133:275-86.

15. Jiang B, Fu X, Yan L, Li S, Zhao D, Wang X, Duan Y, Yan Y, Li E, Wu K, Inglis BM, Ji W, Xu RH, Si W. Transplantation of human ESC-derived mesenchymal stem cell spheroids ameliorates spontaneous osteoarthritis in rhesus macaques. Theranostics. 2019;9(22):6587-600.

16. Mustafa NR, de Winter W, van Iren F, Verpoorte R. Initiation, growth and cryopreservation of plant cell suspension cultures. Nat Protoc. 2011;6(6):715-42.

17. Roy S, Arora S, Kumari P, Ta M. A simple and serum-free protocol for cryopreservation of human umbilical cord as source of Wharton's jelly mesenchymal stem cells. Cryobiology. 2014;68(3):467-72.

18. Ting L, Rad R, Gygi SP, Haas W. MS eliminates ratio distortion in isobaric multiplexed quantitative proteomics. Nat Methods. 2011;8(11):937-40.

19. De Rosa A, De Francesco F, Tirino V, Ferraro GA, Desiderio V, Paino F, Pirozzi G, D'Andrea F, Papaccio G. A new method for cryopreserving adiposederived stem cells: an attractive and suitable large-scale and long-term cell banking technology. Tissue Eng Part C Methods. 2009;15(4):659-67.

20. Fong CY, Subramanian A, Biswas A, Gauthaman K, Srikanth P, Hande MP, Bongso A. Derivation efficiency, cell proliferation, freeze-thaw survival, stem-cell properties and differentiation of human Wharton's jelly stem cells. Reprod Biomed Online. 2010;21(3):391-401.

21. Woods EJ, Perry BC, Hockema JJ, Larson L, Zhou D, Goebel WS. Optimized cryopreservation method for human dental pulp-derived stem cells and their tissues of origin for banking and clinical use. Cryobiology. 2009;59(2):150-7.

22. Nekanti U, Mohanty L, Venugopal P, Balasubramanian S, Totey S, Ta M. Optimization and scale-up of Wharton's jelly-derived mesenchymal stem cells for clinical applications. Stem Cell Res. 2010;5(3):244-54.

23. Marquez-Curtis LA, Janowska-Wieczorek A, McGann LE, Elliott JA. Mesenchymal stromal cells derived from various tissues: biological, clinical and cryopreservation aspects. Cryobiology. 2015;71(2):181-97.

24. Moll G, Alm JJ, Davies LC, von Bahr L, Heldring N, Stenbeck-Funke L, Hamad OA, Hinsch R, Ignatowicz L, Locke M, Lönnies H, Lambris JD, Teramura Y, Nilsson-Ekdahl K, Nilsson B, Le Blanc K. Do cryopreserved mesenchymal stromal cells display impaired immunomodulatory and therapeutic properties? Stem Cells. 2014;32(9):2430-42.

25. François M, Copland IB, Yuan S, Romieu-Mourez R, Waller EK, Galipeau J. Cryopreserved mesenchymal stromal cells display impaired immunosuppressive properties as a result of heat-shock response and impaired interferon- $\gamma$ licensing. Cytotherapy. 2012;14(2):147-52.

26. Hoogduijn MJ, de Witte SF, Luk F, van den Hout-van Vroonhoven MC, Ignatowicz L, Catar R, Strini T, Korevaar SS, van IJcken WF, Betjes MG, Franquesa M, Moll G, Baan CC. Effects of freeze-thawing and intravenous infusion on mesenchymal stromal cell gene expression. Stem Cells Dev. 2016;25(8):586-97.

27. Chinnadurai R, Garcia MA, Sakurai Y, Lam WA, Kirk AD, Galipeau J, Copland IB. Actin cytoskeletal disruption following cryopreservation alters the biodistribution of human mesenchymal stromal cells in vivo. Stem Cell Rep. 2014;3(1):60-72.

28. Page P, DeJong J, Bandstra A, Boomsma RA. Effect of serum and oxygen concentration on gene expression and secretion of paracrine factors by mesenchymal stem cells. Int J Cell Biol. 2014;2014:601063.

29. Pollock K, Samsonraj RM, Dudakovic A, Thaler R, Stumbras A, McKenna $\mathrm{DH}$, Dosa PI, van Wijnen AJ, Hubel A. Improved post-thaw function and epigenetic changes in mesenchymal stromal cells cryopreserved using multicomponent osmolyte solutions. Stem Cells Dev. 2017;26(11):828-42. 
30. Chetty C, Lakka SS, Bhoopathi P, Kunigal S, Geiss R, Rao JS. Tissue inhibitor of metalloproteinase 3 suppresses tumor angiogenesis in matrix metalloproteinase 2-down-regulated lung cancer. Cancer Res. 2008;68(12):4736-45.

31. Uchinaka A, Kawaguchi N, Mori S, Hamada Y, Miyagawa S, Saito A, Sawa Y, Matsuura N. Tissue inhibitor of metalloproteinase-1 and -3 improves cardiac function in an ischemic cardiomyopathy model rat. Tissue Eng Part A. 2014;20(21-22):3073-84.

32. Mariani Costantini R, Falcioni R, Battista P, Zupi G, Kennel SJ, Colasante A, Venturo I, Curio CG, Sacchi A. Integrin (alpha 6/beta 4) expression in human lung cancer as monitored by specific monoclonal antibodies. Cancer Res. 1990;50(18):6107-12.

33. Castaldo C, Di Meglio F, Nurzynska D, Romano G, Maiello C, Bancone C, Müller P, Böhm M, Cotrufo M, Montagnani S. CD117-positive cells in adult human heart are localized in the subepicardium, and their activation is associated with laminin-1 and alpha 6 integrin expression. Stem Cells. 2008;26(7):1723-31.

34. Okudela K, Mitsui H, Woo T, Kojima Y, Matsumura M, Arai H, Suzuki T, Umeda S, Tateishi Y, Saito Y, Tajiri M, Masuda M, Kameda Y, Ohashi K. Expression of tropomyosins in lung cancer-a potential role in carcinogenesis and its utility in a histopathological diagnosis. Histol Histopathol. 2016;31(8):857-66.

35. Rajan S, Jagatheesan G, Petrashevskaya N, Biesiadecki BJ, Warren CM, Riddle T, Liggett S, Wolska BM, Solaro RJ, Wieczorek DF. Tropomyosin pseudo-phosphorylation results in dilated cardiomyopathy. J Biol Chem. 2019;294(8):2913-23.

36. Lee MW, Kim DS, Yoo KH, Kim HR, Jang IK, Lee JH, Kim SY, Son MH, Lee SH, Jung HL, Sung KW, Koo HH. Human bone marrow-derived mesenchymal stem cell gene expression patterns vary with culture conditions. Blood Res. 2013;48(2):107-14.

37. Xu X, Liu Y, Cui Z, Wei Y, Zhang L. Effects of osmotic and cold shock on adherent human mesenchymal stem cells during cryopreservation. J Biotechnol. 2012;162(2-3):224-31.

38. Yang YK, Ogando CR, Wang See C, Chang TY, Barabino GA. Changes in phenotype and differentiation potential of human mesenchymal stem cells aging in vitro. Stem Cell Res Ther. 2018;9(1):131.

39. de Witte SFH, Lambert EE, Merino A, Strini T, Douben HJCW, O'Flynn L, Elliman SJ, de Klein AJEMM, Newsome PN, Baan CC, Hoogduijn MJ. Aging of bone marrow- and umbilical cord-derived mesenchymal stromal cells during expansion. Cytotherapy. 2017;19(7):798-807.

40. Facchin F, Bianconi E, Romano M, Impellizzeri A, Alviano F, Maioli M, Canaider S, Ventura C. Comparison of oxidative stress effects on senescence patterning of human adult and perinatal tissue-derived stem cells in short and long-term cultures. Int J Med Sci. 2018;15(13):1486-501.

41. De Witte SFH, Peters FS, Merino A, Korevaar SS, Van Meurs JBJ, O'Flynn L, Elliman SJ, Newsome PN, Boer K, Baan CC, Hoogduijn MJ. Epigenetic changes in umbilical cord mesenchymal stromal cells upon stimulation and culture expansion. Cytotherapy. 2018;20(7):919-29.

42. Wiese DM, Ruttan CC, Wood CA, Ford BN, Braid LR. Accumulating transcriptome drift precedes cell aging in human umbilical cord-derived mesenchymal stromal cells serially cultured to replicative senescence. Stem Cells Transl Med. 2019;8(9):945-58.

43. Izadpanah R, Kaushal D, Kriedt C, Tsien F, Patel B, Dufour J, Bunnell BA Long-term in vitro expansion alters the biology of adult mesenchymal stem cells. Cancer Res. 2008;68(11):4229-38.
44. Zhang DY, Wang HJ, Tan YZ. Wnt/ $\beta$-catenin signaling induces the aging of mesenchymal stem cells through the DNA damage response and the p53/p21 pathway. PLoS ONE. 2011;6(6):e21397.

45. Duscher D, Rennert RC, Januszyk M, Anghel E, Maan ZN, Whittam AJ, Perez MG, Kosaraju R, Hu MS, Walmsley GG, Atashroo D, Khong S, Butte AJ, Gurtner GC. Aging disrupts cell subpopulation dynamics and diminishes the function of mesenchymal stem cells. Sci Rep. 2014;4:7144.

46. Fafián-Labora J, Fernández-Pernas P, Fuentes I, De Toro J, Oreiro N, Sangiao-Alvarellos S, Mateos J, Arufe MC. Influence of age on rat bonemarrow mesenchymal stem cells potential. Sci Rep. 2015;5:16765.

47. Ohkouchi S, Block GJ, Katsha AM, Kanehira M, Ebina M, Kikuchi T, Saijo Y, Nukiwa T, Prockop DJ. Mesenchymal stromal cells protect cancer cells from ROS-induced apoptosis and enhance the Warburg effect by secreting STC1. Mol Ther. 2012;20(2):417-23.

48. He Y, Xu LL, Feng FE, Wang QM, Zhu XL, Wang CC, Zhang JM, Fu HX, $X u L P$, Liu KY, Huang XJ, Zhang XH. Mesenchymal stem cell deficiency influences megakaryocytopoiesis through the TNFAIP3/NF-KB/SMAD pathway in patients with immune thrombocytopenia. Br J Haematol. 2018;180(3):395-411.

49. Chamberlain JR, Deyle DR, Schwarze U, Wang P, Hirata RK, Li Y, Byers PH, Russell DW. Gene targeting of mutant COL1A2 alleles in mesenchymal stem cells from individuals with osteogenesis imperfecta. Mol Ther. 2008;16(1):187-93.

50. Ball SG, Shuttleworth CA, Kielty CM. Platelet-derived growth factor receptors regulate mesenchymal stem cell fate: implications for neovascularization. Expert Opin Biol Ther. 2010;10(1):57-71.

51. Mruthyunjaya S, Rumma M, Ravibhushan G, Anjali S, Padma S. c-Jun/AP-1 transcription factor regulates laminin-1-induced neurite outgrowth in human bone marrow mesenchymal stem cells: role of multiple signaling pathways. FEBS Lett. 2011;585(12):1915-22.

52. Tomé M, Sepúlveda JC, Delgado M, Andrades JA, Campisi J, González MA, Bernad A. miR-335 correlates with senescence/aging in human mesenchymal stem cells and inhibits their therapeutic actions through inhibition of AP-1 activity. Stem Cells. 2014;32(8):2229-44.

53. Lee DS, Yi TG, Lee HJ, Kim SN, Park S, Jeon MS, Song SU. Mesenchymal stem cells infected with mycoplasma arginini secrete complement C3 to regulate immunoglobulin production in B lymphocytes. Cell Death Dis. 2014;5:e1192.

54. Itaba N, Matsumi Y, Okinaka K, Ashla AA, Kono Y, Osaki M, Morimoto M, Sugiyama N, Ohashi K, Okano T, Shiota G. Human mesenchymal stem cell-engineered hepatic cell sheets accelerate liver regeneration in mice. Sci Rep. 2015:5:16169.

55. Neuss S, Becher E, Wöltje M, Tietze L, Jahnen-Dechent W. Functional expression of HGF and HGF receptor/c-met in adult human mesenchymal stem cells suggests a role in cell mobilization, tissue repair, and wound healing. Stem Cells. 2004;22(3):405-14.

\section{Publisher's Note}

Springer Nature remains neutral with regard to jurisdictional claims in published maps and institutional affiliations.

Ready to submit your research? Choose BMC and benefit from

- fast, convenient online submission

- thorough peer review by experienced researchers in your field

- rapid publication on acceptance

- support for research data, including large and complex data types

- gold Open Access which fosters wider collaboration and increased citations

- maximum visibility for your research: over 100M website views per year

At BMC, research is always in progress.

Learn more biomedcentral.com/submissions 